\title{
Does Investors' Divergence of Opinion Affect Stock Mispricing?
}

\author{
Diogo Silva*, António Cerqueira, Elísio Brandão \\ School of Economics and Management, University of Porto
}

\section{ARTICLE INFO}

\section{Article history:}

Received 31 October 2020

Revised 08 January 2021

Accepted 26 January 2021

Published 08 February 2021

\section{Keywords:}

Divergence of opinion

Stock mispricing

JEL classification: G14

\begin{abstract}
The main purpose of this study is to address the association between investors' divergence of opinion (DIVOP) and stock mispricing for UK firms listed in the London Stock Exchange Market. Previous research on this topic has provided mixed results. Some studies provide evidence consistent with the overpricing hypothesis, which indicates that DIVOP leads to overpricing because the market overweighs the most optimistic valuations, since optimistic investors can always buy a stock but pessimistic investors can only sell a stock if they already own it or need rely on short-selling, which has costs. Other studies support the underpricing hypothesis, which proposes that DIVOP works as a price risk factor that generates underpricing. We develop an empirical analysis that do not depend on the interpretation of abnormal future stock returns to assess contemporaneous mispricing. We use five explicit measures of mispricing. Also, to safeguard the development of a comprehensive study, we use three kinds of proxies of DIVOP, based on idiosyncratic volatility, dispersion in analysts' forecasts and unexpected trading volume. The results show a positive significant association between DIVOP and stock mispricing on a yearly basis. This association is stronger for underpriced stocks, which is consistent with the underpricing hypothesis, and indicates that DIVOP signals risk. An implication of this study is that firms have incentives to provide highquality and explicit information to limit DIVOP and avoid being underpriced.
\end{abstract}

\section{Introduction}

Stock mispricing is always a topic under great scrutiny (Keloharju et al., 2020; Xiong et al., 2020; Zhang et al., 2020), because, even tough, financial theory usually assumes that prices do not systematically deviate from fundamental values (Doukas et al., 2010), the literature has shown that it may be pervasive and persist for some time (Jarrow and O'Hara, 1989; Pontiff, 1996, Jacobs and Muller, 2020), affecting many dimensions of financial markets, such as investment decisions (Chang et al., 2007), leverage dynamics (Warr et al., 2012), takeover activity (Dong et al., 2006) and mergers (Rhodes-Kropf et al, 2005).

Similarly, there has been as increasing interest on the impact of behavioural factors on financial markets, such as divergence of opinion (DIVOP) (Al-Nasseri and Ali, 2018; Gao et al., 2020; Hu et al., 2020). In this study, we analyse the association between DIVOP and stock mispricing for UK firms listed on the London stock exchange market. There are two theories that provide theoretical background for this relationship. Firstly, Miller (1977) hypothesize that in the presence of DIVOP, the market will overweigh the most optimistic valuations, because while optimistic investors can always buy a stock, pessimistic investors can only sell a stock if they already own it. Pessimistic investors may also rely on short-selling but it can be costly (Stambaugh et al., 2015). According to Miller's hypothesis, DIVOP will tend to translate in the overpricing of stocks. The second theory is grounded on Merton (1987), who develops a CAPM based model that suggests that investors may have different preferences due to information asymmetry. As a result, investors will hold undiversified portfolios, incurring in higher risks. In Merton's setting, investors will demand higher stock returns which will lead to underpricing.

* Corresponding author.

E-Mail address:dsilva@fep.up.pt

ORCID: 0000-0002-4368-0099 
Both these theories indicate that DIVOP is associated with stock mispricing, but while Miller's hypothesis suggests that DIVOP leads to overpricing, Merton's framework is consistent with DIVOP translating in underpricing. Prior research has addressed the relationship between DIVOP and stock mispricing but the evidence produced is inconsistent and mixed.

To our knowledge Diether et al. (2002) are the first to present evidence of the overpricing hypothesis. The authors use dispersion in analysts' forecasts (DISP) to proxy DIVOP and find that stocks with larger DIVOP have lower stock returns in the month that follows. They do not show support of Merton (1987), instead their evidence is consistent with Miller (1977). Still, other studies have shown that the findings of Diether et al., (2002) are not robust to financial leverage or the post-earnings announcement drift phenomenon (Johnson, 2004; Chen and Jiambalvo, 2004). Nevertheless, further research presents empirical evidence consistent with Diether et al. (2002). Park (2005) shows that DIVOP is associated with aggregate lower returns. Berkman et al. (2009) find that stocks with larger DIVOP present lower returns in the days that immediately follow the earnings announcement date. Also, Yu (2011) shows that DIVOP at the portfolio level is associated lower returns. Neverthless, recent research suggests that the previous results only hold for bull market periods (Al-Nasseri and Ali, 2018) and that the ability of DISP to predict lower returns is concentrated around earnings announcement dates (Veenman and Verwijmeren, 2020).

On the other side, there are a couple of papers that present theoretical models consistent with Merton (1987) (Varian, 1985; Andersen et al., 2005, Basak, 2005; David, 2008). Varian (1985) use an Arrow-Debreu based model to show that DIVOP is associated with underpricing. Andersen et al. (2005) implement dynamic general equilibrium models and show that DIVOP is a price risk factor. David (2008) develops a theoretical model in which investors have different opinions about fundamental growth and as a result they demand higher stock returns. Pure empirical evidence consistent with Merton (1987) is scarcer. Until very recently we could only point the work of Doukas et al. (2006a) and (Carlin et al., 2014). Doukas et al. (2006a) reproduces the tests of Diether et al. (2002) but applies the methodology proposed by Barron et al. (1998) to proxy DIVOP. Carlin et al. (2014) focuses on the opinions of Wall Street mortgage dealers about prepayment speeds. Nevertheless, recently, Cao et al. (2020) find that low investor attention leads to both DIVOP and lower stocks returns. This evidence is in favor of the underpricing hypothesis. The findings of Cao et al. (2020) are consistent with Boehme et al. (2009), who highlight that the overpricing hypothesis does not hold for low visibility stocks. Note that low visibility stocks are more likely to suffer from low investor attention.

Regarding the research that supports Miller (1977), we enhance three aspects. Firstly, they tend to focus on the short-term association between DIVOP and stock mispricing (monthly perspective or days after earnings announcement date). Secondly, all of them interpret lower future stock returns as signalling contemporaneous overpricing and higher future stock returns as translating contemporaneous underpricing. Thirdly, most of them depend on DISP to proxy for DIVOP. When it comes to evidence of the underpricing hypothesis, which is consistent with Merton's settings, we highlight that available empirical evidence is scarce and almost inexistent regarding equity stocks. Most of the evidence rely on theoretical models that are now dated.

Our study offers four new features to the discussion of the association between DIVOP and stock mispricing. Firstly, we develop an empirical analysis that do not depend on the interpretation of abnormal future stock returns to assess contemporaneous mispricing. We literally measure mispricing. To our knowledge, ours is the first study to actually associate DIVOP with explicit measures of mispricing. Aabo et al. (2017) compute a total of five measures and we reproduce all five in our tests. The first is based on Frankel and Lee (1998) who are able to compare current market value with a theoretical firm value. The second measure of mispricing compares current market value with an expected market value that depends on a couple of attributes (Rhodes-Kropf et al., 2005). The third measure is based on a comparison between firms' capital to sales ratio and their corresponding industry (Berger and Ofek, 1995). The forth measure considers the difference between firms' market to book ratio and their industry peers (Walkling and Edmisted, 1985; Rau and Vermaelen, 1998). The last measure is an index that sums up all previous measures (Aabo et al., 2017).

Secondly, almost all existing empirical evidence depends on DISP to proxy DIVOP. DISP is an interesting measure of DIVOP because it provides a representation of investors' opinions (Nichols, 1989; Schipper, 1991). Nevertheless, this proxy may be affected by common uncertainty (Barron et al., 1998; Doukas et al., 2006a) and it may not be possible to compute it to firms with low analyst coverage, which may bias the analysis (Boheme et al., 2009). To safeguard the development of a comprehensive study, we use three kinds of proxies of DIVOP. We compute DISP, in line with most literature (Diether et al., 2002; Park, 2005; Chatterjee et al., 2012). In addition, we follow Berkman et al. (2009) and also use idiosyncratic volatility (IVOL) to proxy DIVOP. In our baseline line tests we use the Fama and French (2015) five factor model to compute IVOL. In alternative tests, we also use the market model (Sharpe, 1963; Fama, 1973), the Fama and French three factor model (1997) and the Carhart (1997) model. 
Last, we consider Garfinkel (2009) and proxy DIVOP with two measures of unexpected trading volume, namely unexplained trading volume (UNVOL) and abnormal trading volume (ABVOL). In the baseline tests, we use unexplained trading volume in the three months prior to the earnings announcement date (UNVOL3), but we also consider unexplained trading volume in the six months prior to the earnings announcement date (UNVOL6), unexplained trading volume in the nine months prior to the earnings announcement date (UNVOL9) and abnormal trading volume in the three months prior to the earnings announcement date (ABVOL3).

Thirdly, we develop an empirical analysis, but while existing literature considered the short-term association between DIVOP and stock mispricing (monthly association or the days after earnings announcement date) we apply a yearly perspective. There is evidence that some factors lead to the temporary mispricing of stocks (Keloharju et al., 2020; Xiong et al., 2020). However, when one uses a longer horizon, these effects tend to dissipate. For instance, although some stocks tend to earn higher returns than other stocks in the same month of every year (Heston and Sadka, 2008), these seasonalities and their corresponding reversals actually sum zero, when one considers a yearly perspective (Keloharju et al., 2020). The identification of an association between DIVOP and stock mispricing is more relevant if it is noticeable using a yearly perspective.

Last, to our knowledge, all empirical research on the relationship between DIVOP and mispricing is focused on the US stock market. We provide evidence for UK firms listed in the London Stock Exchange Market, which is one of Europe's largest stock markets.

Our main findings can be described as follows: The results show a positive significant association between DIVOP and stock mispricing on a yearly basis. More importantly, this association is stronger for underpriced stocks. In this regard, our study supports Merton (1987). Theoretically, this hints that DIVOP works as an information risk. This is in line with Jiang et al. (2009), Rajgopal and Venkatachalam (2011) and Berrada and Hugonnier (2013), who associate information risk with idiosyncratic risk, which affects stock returns in Merton's model. It is also consistent with Andersen et al. (2005) who suggests that DIVOP is a price risk factor and with a recent study by Cao et al. (2020), who link low investor attention, DIVOP and lower returns. Finally, the difference between underpriced and overpriced stocks is the largest when we focus on small firms and also when we proxy DIVOP using IVOL. This is consistent with IVOL capturing not only DIVOP but also other idiosyncratic risks.

The remainder of this study is organised as follows: Section 2 presents the literature review; Section 3 displays the methodological procedures; Section 4 shows the results of the empirical tests; Section 5 presents the conclusion.

\section{Literature review}

The association between DIVOP and stock mispricing is grounded on two fundamental theories. The first refers to Miller (1977), who argues that DIVOP leads to mispricing if there are short-selling constraints. This happens because optimistic investors can always buy a stock but pessimistic investors must hold the asset in order to sell it or rely on short-selling (which may be too costly). As a result, especially when there are short-selling constraints, DIVOP will generate overpricing. For instance, Stambaugh et al. (2015) shows that arbitrage asymmetry, such as short-selling constraints, can explain the negative association between IVOL and expected returns (monthly association) for overpriced stocks.

The second theory that justifies a relationship between DIVOP and mispricing is based on Merton (1987). The author discloses a model setting consistent with CAPM but that can accommodate idiosyncratic risk in equilibrium. In this model, investors have incomplete information and each of them tend to prefer the stocks they are familiar with. Indeed, DIVOP tends to be a reflection of information risk. For instance, Rajgopal and Venkatachalam (2011) show that financial reporting quality is positively associated with IVOL (a proxy of DIVOP) and Berkman et al (2009) show that DIVOP tends to be lower for older firms because they have a greater operational history that limits uncertainty. In Merton's model, investors will hold undiversified portfolios because each of them will prefer the stocks they are familiar with. As a result, they will be exposed to higher risks. According to the model's setting, investors will also demand higher returns, due to the higher risks that arise from owning undiversified portfolios. Consequently, heterogeneity in investors' preferences will translate in underpricing, indicating that DIVOP works as a price risk factor. Indeed, the

Both these theories point out that DIVOP leads to stock mispricing. Still, they have opposing channels through which they generate mispricing. While Miller's hypothesis indicates that DIVOP leads to mispricing by the means of overpricing, Merton's setting suggests that DIVOP induces mispricing through underpricing. Researchers have been addressing these theories, but the available evidence is mixed and contradictory. There are empirical literature pointing to the overpricing hypothesis (Diether et al., 2002; Park, 2005; Berkman et al., 2009; Yu, 2011; Chatterjee 
et al., 2012, Qian, 2014) but also literature supporting the underpricing hypothesis (Varian, 1985; Andersen et al., 2005; Basak, 2005; Doukas et al., 2006a; David, 2008; Carlin et al., 2014; Cao et al., 2020).

To our knowledge Diether et al. (2002) are the first to present evidence of the overpricing hypothesis. The authors use DISP to measure DIVOP and find that DIVOP is associated with lower returns in the month that follows. Diether et al. (2002) conclude that the results reject the idea that DIVOP can be seen as a proxy of risk, which is inconsistent with Merton (1987) and in line with (Miller, 1977). Nevertheless, Diether et al. (2002) received some criticism. For instance, Johnson (2004) shows that the findings of Diether et al. (2002) are not robust to financial leverage and Chen and Jiambalvo (2004) point out that their results can be explained by the post-earnings announcement drift phenomenon.

Similar to Diether et al. (2002), Park (2005) rely on DISP and monthly data, but focus on the relationship between DIVOP and future aggregate stock returns. His findings are similar to Diether et al. (2002). Yu (2011) also finds empirical evidence consistent with the Miler's hypothesis using DISP to proxy DIVOP. The author addresses the impact of DIVOP, in terms of stock returns, at the portfolio level. Chatterjee et al (2012) analyze the effect of DIVOP on takeovers. They show that the takeover premium is higher when DIVOP is larger.

Berkman et al. (2009) analyse the days that immediately follow the earnings announcement date. They indicate that earnings announcements should reduce DIVOP due to the increase in information, providing a good context to evaluate the impact of DIVOP on stock returns. Berkman et al. (2009) find that stocks with larger DIVOP earn lower returns immediately after the earnings announcement date and that the impact of higher DIVOP is even larger when there are short-selling constraints. Also, Qian (2014) provides a more specific picture, even tough, consistent with the Miller's hypothesis. The author shows that high retail investor sentiment leads to increasing overpricing when DIVOP is higher.

Research supporting the overpricing hypothesis is not scarce but tends to be too focused. For instance, these studies tend to be short-term driven, by considering the short-term (monthly) association between DIVOP and stock returns or the days that immediately follow the earnings announcement date. Recent research shows that the previous results only hold for bull market periods (Al-Nasseri and Ali, 2018) and that the ability of DIVOP (measured by DISP) to predict lower returns is concentrated around earnings announcement dates (Veenman and Verwijmeren, 2020). Also, available evidence supporting Miller's hypothesis is usually highly dependent on DISP to measure DIVOP. It is likely the most used proxy of DIVOP. The argument behind its use is that analyst' forecasts are a reflection of investors' opinions (Nichols, 1989; Schipper, 1991). However, as pointed by Barron et al. (1998) and Doukas et al. (2006a) there is the risk that it captures not only DIVOP but also overall uncertainty. Also, DISP can only be computed for firms that are followed by analysts. For instance, Boheme et al. (2009) show that idiosyncratic risk is positively related with stock returns for stocks with low analyst coverage. This relationship is a direct implication of Merton's model. Besides those firms with low analyst coverage are automatically excluded from studies that depend only on the computation of DISP. Note that for these studies, this kind of data needs to be available on a monthly basis, because these analyses usually apply a monthly perspective. Moreover, Garfinkel (2009) show that there are other measures of DIVOP that have better properties than DISP.

Regarding the underpricing hypothesis, which is consistent with Merton (1987), one can highlight the studies of Varian (1985), Andersen et al. (2005), Basak (2005), Doukas et al. (2006a), David (2008), Carlin et al. (2014) and Cao et al. (2020).

Interestingly, Varian (1985) proposes that DIVOP leads to underpricing even before Merton (1987) presented his research. Similar to Merton (1987), Varian (1985) develops a neoclassical approach, by developing an Arrow-Debreu model. Varian's analysis suggests that an asset will have a lower price when DIVOP is higher, if risk aversion does not decline too rapidly. Andersen et al. (2005) empirically implement dynamic general equilibrium models in which they consider investors with different opinions. Their tests show that DIVOP has explanatory power after considering other standard risk factors, such as size and book-to-market (Fama and French, 1997). Using a general equilibrium model, Basak (2005) finds similar results and suggests that these results should be put to test empirically. David (2008) develops a theoretical model in which investors have different opinions about fundamental growth and as a result they demand higher equity returns.

Doukas et al. (2006a) reproduce the empirical analysis developed by Diether et al. (2002) but apply a different measure of DIVOP that has been proposed by Barron et al. (1998). Their results are opposite to the ones obtained by Diether et al. (2002) and consistent with Merton's setting. Carlin et al. (2014) also develops an empirical analysis, but focuses on the opinions of Wall Street mortgage dealers about prepayment speeds. The authors find that increased DIVOP is associated with higher returns, which suggests than, at least in this context, DIVOP is related with underpricing. Overall, when it comes to evidence of the underpricing hypothesis, the empirical evidence is scarce and almost inexistent regarding equity stocks. Most of the evidence rely on theoretical models that are now dated. The 
exception is a recent work by Cao et al. (2020) who find that low investor attention leads to both DIVOP and lower stocks returns, which support the underpricing hypothesis.

In our study we develop an empirical analysis. But instead of focusing on the short-term (monthly) association between DIVOP and stock mispricing, we address this relationship using a longer horizon by considering a yearly perspective. We tolerate that DIVOP may boost mispricing in the short-term due to market imperfections, but the relevance of this association depends on how structural it can be. Although some market imperfections may lead to mispricing (Keloharju et al., 2020; Xiong et al., 2020), their impact tends to dissipate in longer horizons. For instance, even though some stocks tend to earn higher returns than other stocks in the same month of every year (Heston and Sadka, 2008), these seasonalities and their reversals add up to zero when one considers a yearly perspective (Keloharju et al., 2020).

In addition, all existing empirical evidence on the association between DIVOP and mispricing, is that researchers do not actually measure mispricing. Researchers interpret lower future stock returns as a sign of contemporaneous overpricing and higher future stock returns as contemporaneous underpricing. We follow a recent study by Aabo et al. (2017) and use five different measures of mispricing. Our study is actually the first to literally test the association between DIVOP and stock mispricing.

Another issue with the empirical evidence that focuses on the relationship between DIVOP and mispricing is that they tend to depend on one measure of DIVOP, usually DISP. We consider a wide array of proxies of DIVOP that go from DISP (Diether et al., 2002), to IVOL (Berkman et al., 2009) or unexpected trading volume (Garfinkel, 2009).

A minor but mentionable point that we need to add is that all empirical evidence cited focus on firms listed on the US, usually firms that are part of the S\&P 500 stock index. While other areas of research have addressed and tested hypothesis on different markets and contexts, the empirical evidence on the association between DIVOP and mispricing has received little attention in this regard.

\section{Methodology}

\section{Data sources and sample}

This study focuses on UK firms listed on the London Stock Exchange Market. Our primary source of data is the Thomson Reuters Datastream. We collect data on analysts' forecasts from the Institutional Brokers Estimate System $(\mathrm{I} / \mathrm{B} / \mathrm{E} / \mathrm{S})$. Data on the time series of European systematic risk factors and the risk-free rate of return is retrieved from the Kenneth R. French website. We extract all the data available from 1998 until 2017. The UK government announced the withdrawal from the European Union in March of 2017. We exclude data from this date onwards. The withdrawal of the UK from the European Union had a persistent impact on the stock market performance of some firms (Ramiah et al., 2017), generating a structural break in these firms time-series. It also had persistent implications on the interactions between the UK stock market and its European peers, having a substantial impact in terms of stock markets co-volatility ( $\mathrm{Li}, 2020)$.

We apply a couple of criteria to adjust our sample. We consider only firm-year observations complaint with International Financial Reporting Standards (IFRS). The objective is to guarantee the comparability of accounting data within firms and throughout the years. Since the mandatory adoption of IFRS started in 2005, the number of observations prior to this year is small because many firms were still applying National General Accepted Accounting Principles (GAAP) or we could not find information about the accounting standards that were being followed.

We associate firms with one of 48 industry categories. To define each firm's industry, we follow Fama and French (1997). We exclude firms from the financial and the utilities sectors. Those correspond to industry codes $31,44,45$, 46, 47, 48. Our final dataset has around 2000 firms. Finally, we windsorise all variables at the first and last percentile.

\section{Mispricing}

To ensure that the results are not proxy specific, we follow Aabo et al. (2017) and compute five measures of mispricing. We consider Frankel and Lee (1998) to develop MISP1. It is computed as follows:

$$
M I S P 1_{i, t}=\ln \left(M V_{i, t} / T V_{i, t}\right)
$$


Where for firm $i$ and year $t$, MV corresponds to market value and TV refers to theoretical value. If estimated value (EV) is smaller than book value, then TV equals BV, otherwise TV equals EV. EV is given by the following formula:

$$
\begin{aligned}
E V_{i, t} & =B V_{i, t}+\left[\left(F R O E_{i, t}-R E_{i, t}\right) /\left(1+R E_{i, t}\right)\right] \cdot B V_{i, t} \\
& +\left[0.5\left(F R O E_{i, t}-R E_{i, t}\right) /\left(1+R E_{i, t}\right) R E_{i, t}\right] \cdot B V_{i, t}
\end{aligned}
$$

Where for firm $i$ and year $t, \mathrm{BV}$ is the book value of equity, FROE refers to future return on equity, which is estimated by current net income (NI) divided by average equity. We exclude observations for which equity at the beginning or at the end of the year is zero or negative. We also windsorise FROE at 0 and 1 . RE corresponds to the industry cost of capital. We estimate industries cost of capital by the ratio between net income and market value. The computation of EV is basically a one-period discounted cash-flow model, in which we assume that in the future the difference between firms' returns and the industry cost of capital will soften by half ${ }^{1}$.

MISP2 is given by the difference between the logarithm of MV and the logarithm of expected MV.

$$
M I S P 2_{i, t}=\ln \left(M V_{i, t}\right)-\ln \left[E\left(M V_{i, t}\right)\right]
$$

To compute the logarithm of expected MV, we follow Rhodes-Kropf et al. (2005) and estimate the following equation:

$$
\begin{gathered}
\operatorname{Ln}\left[E\left(M V_{i, t}\right)\right]=B_{0}+B_{1 \cdot} \ln \left(B V_{i, t}\right)+B_{2} \cdot \text { positive_NI } I_{i, t} \ln \left(N I_{i, t}\right) \\
+B_{3 .} \text { negative_NI } I_{i, t} \ln (N I)_{i, t}+B_{4 \cdot} L E V_{i, t}+e_{i, t}
\end{gathered}
$$

Where for firm $i$ and year $t$, positive_NI is a dummy variable that equals one when NI is positive and negative_NI corresponds to a dummy variable that equals one when NI is negative. LEV is long-term debt divided by total assets. The equation is estimated for each industry-year with at least 10 observations. The aim of this approach is to firstly model the logarithm of firms' market value. Then, we compare firms' actual market value with the expected market value (given by the model). The difference between the two corresponds to the MISP2. The use of logarithms is relevant of address scaling issues and serial correlation.

MISP3 is based on the procedure used by Berger and Ofek (1995). It is basically a comparison between the firms' capital to sales ratio with the industry median. The following formula is applied:

$$
\operatorname{MIPS}_{i, t}=\ln \left(C T S_{i, t} / \operatorname{ICTS}_{i, t}\right)
$$

Where for firm $i$ and year $t$, CTS is the firm's capital to sales ratio and ICTS refers to the median capital to sales ratio of the firm's corresponding industry. Capital to sales ratio is the sum of market value and total debt, both divided by sales. Theoretically, both equity and debt are seen as the total capital invested in a firm. By computing the capital to sales ratio, we identify capital invested by unit of sales, which corresponds to a relative measure of capital and allows for comparability within firms of the same industry. For each firm, we compare its sales per unit of capital with its industry peers. For instance, a firm is underpriced (MISP $3<0$ ) when its sales are higher than its industry peers and it has the same (or lower) capital invested.

Following Walkling and Edmisted (1985) and Rau and Vermaelen (1998), MISP4 compares the firms' marketto-book ratio with its industry median:

\footnotetext{
${ }^{1}$ This parameter does not affect if a stock is underpriced or overpriced. It does influence how mispriced it is. We choose a medium cut-off. We follow Frankel and Lee (1998) and check the impact of using different assumptions about whether and how firms FROE tend to industry values and also the speed at which this process occurs. It does not significantly change the outcome.
} 


$$
\operatorname{MIPS4}_{i, t}=\ln \left(M T B_{i, t} / I M T B_{i, t}\right)
$$

Where for firm $i$ and year $t$, MTB is the market-to-book ratio and IMTB is the median market-to-book ratio of the firm's corresponding industry. The main caveat of this measure is that the market-to-book ratio also proxies for growth opportunities. Nevertheless, there should be some correlation between firms' growth opportunities within the same industry. Since we compare each firm market-to-book ratio with the median of its industry, this issue is not expected to play a relevant role.

MISP5 is an index developed by Aabo et al. (2017). It is the average of four adjusted rankings. Each ranking relates with one of the four measures of mispricing (MISP1, MISP2, MISP3 and MISP4). Each of the adjusted rankings are computed as follows:

$$
\operatorname{RMISP}_{j, i, t}=\operatorname{RANK}\left[\operatorname{Abs}\left(\operatorname{MISP}_{j, i, t}\right)\right] / N_{j}
$$

Where for firm $i$ and year $t, \operatorname{Abs}\left(\operatorname{MISP}_{j}\right)$ is the absolute value of MISP $j . \mathrm{N}_{\mathrm{j}}$ is the number of observations for MISP $j$. RANK represents the order of the observations for MISP $j$, from the least mispriced observation to the most mispriced $\left(\mathrm{N}_{j}\right)$. We scale each ranking by the corresponding number of observations, which ensures that each of them goes from 0 to 1 . This warrants that the scale of each ranking is not determined by the number of observations available for each ranking and that the rankings are comparable. MISP5 is then computed as follows:

$$
\operatorname{MISP}_{i, t}=\sum^{j}\left(R M I S P_{j, i, t}\right) / K_{j}
$$

Where for firm $i$ and year $t, \mathrm{~K}_{j}$ is the number of adjusted rankings (RMISP's) available for a given firm-year. Thus, MISP5 is basically the average of the adjusted rankings (RMISP's) computed for each firm-year. Overall, each mispricing measure has advantages and weaknesses. MISP5 has the benefit of conciliating the four previous measures, allowing one to retain the general tendency provided by the different measures of mispricing, which have different perspectives embedded.

\section{Idiosyncratic volatility (IVOL)}

The main measure of IVOL relies on the Fama and French (2015) five factor model. We define this measure as IV_FF5. Specifically, for each year we run the following regression:

$$
\begin{aligned}
\left(R_{i, t}-R f_{t}\right) & =B_{0}+B_{1 .}\left(R m_{t}-R f_{t}\right)+B_{2 .} S M B_{t}+B_{3 .} \cdot H M L_{t} \\
& +B_{4 .} R M W_{t}+B_{5 .} C M A_{t}+e_{i, t}
\end{aligned}
$$

Where for firm $i$ and day $t, \mathrm{R}$ refers to realised stock return, $\mathrm{Rf}$ corresponds to the risk-free rate of return, $\mathrm{Rm}$ is the return on the value-weight market portfolio, SMB is the return on a diversified portfolio of small stocks minus the return on a diversified portfolio of big stocks, HML refers to the difference between the returns on diversified portfolios of high and low book-to-market stocks, RMW is the difference between the returns on diversified portfolios of stocks with robust and weak profitability and CMA corresponds to the difference between the returns on diversified portfolios of stocks with conservative and aggressive investing stocks. The equation is estimated for each firm-year. Then, for each month, we calculate monthly volatility of idiosyncratic returns by the standard deviation of the residuals of equation 1.9. For each year, we compute IV_FF5 as the average of monthly volatility of idiosyncratic returns. Rajgopal and Venkatachalam (2011) apply the same procedure but use the Fama and French (1993) three factor model. 
For robustness checks we consider alternative measures of IVOL. Instead of relying on the Fama and French (2015) five factor model we use the market model (Sharpe, 1963; Fama, 1973), the Fama and French (1993) three factor model and the Carhart (1997) model. We define these measures of IVOL as IV_MKT, IV_FF3 and IV_MOM.

\section{Unexpected trading volume}

The main measure of DIVOP is based on unexplained trading volume (UNVOL). Its computation is similar to Garfinkel and Sokobin (2006) and Garfinkel (2009). UNVOL equals average monthly unexplained trading volume. Monthly UNVOL corresponds to the residuals of the following regression:

$$
V O L_{i, t}=B_{0}+B_{1 \cdot} \mid \text { positive_ } R_{i, t}\left|+B_{2 \cdot}\right| \text { negative_ } R_{i, t} \mid+e_{i, t}
$$

Where for firm $i$ and month $t$, positive_R corresponds to the logarithm of positive returns and negative_R refers to the logarithm of the absolute value of negative returns. Following Garfinkel (2009), we consider positive and negative returns separately because the relationship between trading volume and the absolute value of returns is different, depending if the returns are positive or negative (Karpoff, 1987). We exclude monthly observations when the stock price has kept constant for three whole months. Han and Lesmond (2011) show the potential bias generated by poor liquidity. Guo and Savickas (2008) cannot confirm whether IVOL signals liquidity risk or DIVOP. Our procedure allows to better control for the impact of poor liquidity. Our main measure of DIVOP is UNVOL3, which equals monthly average unexplained trading volume in the three months prior to the disclosure of earnings per share (EPS) announcement date. We use unexplained trading volume as a primary indicator of DIVOP because it evaluates DIVOP based on the interaction between price changes (returns) and trading volumes. The reader may consider a theoretical situation in which a stock is believed by most investors to be underpriced. Most investors will have incentives to trade and buy the stock, pressuring its price to go up. There will be mainly an increase in the demand for that stock and the price is likely to adjust pretty fast. As an alternative, the reader may conceive an extreme case of DIVOP in which half of the investors believe a stock is highly underpriced and the other half believes the stock is seriously overpriced. Assuming that there are no market frictions, all investors have incentives to trade. Investors who believe the stock is underpriced will buy, while investors who believe the stock is overpriced are going to sell. In this extreme case of DIVOP, the price may not change much and the returns should be minor, still most investors will keep having incentives to trade. As a result, returns will be minor but trading volume will be high. Overall, we expect low absolute returns and high trading volume when DIVOP is high and high absolute returns and low trading volume when DIVOP is low. This inference is in line with Beaver (1968) and Kim and Verrechia (1991a, 1991b). UNVOL indicates the extent to which returns can explain trading volumes. When returns are relatively low compared to trading volumes, UNVOL will display high values. When returns are relatively high compared to trading volumes, then UNVOL will be lower.

In additional tests we consider alternative measures of DIVOP. UNVOL6 refers to monthly average unexplained trading volume in the six months prior to the disclosure of EPS. UNVOL9 corresponds to monthly average unexplained trading volume in the nine months prior to the disclosure of EPS. The computation of UNVOL6 and UNVOL9 is very similar to UNVOL3, being the only difference the number of months considered prior to the EPS announcement date. Besides those, we use an additional measure of DIVOP based on trading volume. It is defined as ABVOL3, and refers to abnormal trading volume in the three months prior to the EPS announcement date. This measure is similar to the one applied by Garfinkel (2009). We compute Monthly ABVOL is calculated as follows:

$$
\begin{aligned}
\text { Monthly_ABVOL }_{i, t} & =\left[\left(V O L_{i, t}-M K T \_V O L_{t}\right)\right] \\
& -\left[\left(F I R M_{-} A V G_{-} V O L_{i}-M K T_{-} A V G_{-} V O L\right)\right]
\end{aligned}
$$

Where for firm $i$ and month $t$, VOL corresponds to shares traded divided by total shares outstanding, MKT_VOL equals total shares traded in the market divided by total shares outstanding in the market, FIRM_AVG_VOL refers to VOL averaged at the firm level and MKT_AVG_VOL is market average trading volume. We use monthly_ABVOL in the three months prior to the EPS announcement date to build ABVOL3. Garfinkel (2009) builds a proxy of DIVOP from proprietary limit order and market order data. Although this kind of data is not usually 
available to researchers, Garfinkel (2009) tests which proxies used in the literature are better correlated with his new proxy. The author concluded that these kind of measures based on trading volume are the best proxies of DIVOP.

\section{Dispersion of analysts' forecasts (DISP)}

Finally, the last measure of DIVOP is dispersion in analysts' forecasts made one year ahead (DISP1). It corresponds to the coefficient of variation of analysts' forecast made one year ahead. It is computed as the standard deviation of forecasts divided by the absolute average of forecasts. This is the most common measure of DIVOP in the literature (Diether et al., 2002; Chen et al., 2002; Berkman et al., 2009; Chatterjee et al., 2012).

\section{Multivariate tests}

The multivariate tests aim at assessing the relationship between DIVOP and mispricing. The baseline tests correspond to the estimation of Equation 1.12:

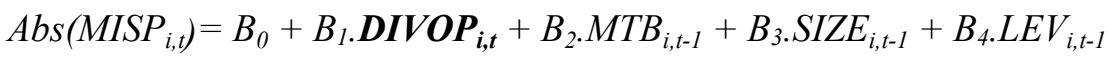

$$
\begin{aligned}
& +B_{5} . R O E_{i, t-1}+B_{6 .} A G E_{i, t-1}+B_{7 .} C F O_{i, t-1}+B_{8} . D I_{V I D} \\
& +B_{9} \cdot \operatorname{DIVER}_{i, t}+B_{10 .} \cdot \operatorname{Abs}\left(\operatorname{MISP}_{i, t-1}\right)+e_{i, t}
\end{aligned}
$$

For each firm $i$ and year $t$, MISP refers to mispricing. Five measures of mispricing are used (MISP1, MISP2, MISP3, MISP4 and MISP5) in independent tests. MISP can be negative or positive, because firms may be underpriced or overpriced. We use the absolute value of MISP because we start by focusing on how mispriced firms are, independently if they are underpriced or overpriced. DIVOP refers to divergence of opinion. We separately estimate Equation 1.12 using different indicators of DIVOP, namely IV_FF5, UNVOL3, UNVOL6, UNVOL9, ABVOL3 and DISP1. We employ several control variables. MTB refers to market-to-book value of equity. SIZE equals the logarithm of market value of equity. LEV measures firms' leverage and corresponds to total debt divided by total assets. We control for firm performance by including ROE in our tests. It refers to return on equity and is computed as net income divided by the book value of equity. AGE corresponds to the logarithm of firms' age. The tests always include both industry and year dummies. DIVID is a dummy variable that equals one if the firm pays dividends. DIVER is a dummy variable that equals one if the firm operates in more than one industry. We follow Fama and French (1997) for the industry classification.

\section{Descriptive statistics and correlations}

Table 1 displays the descriptive statistics of the main variables of this study. MISP1 has a mean of 0.014 and a median of -0.004 . These values are rather close to zero on aggregate because overpriced stocks (MISP1 $>0$ ) are compensating for underpriced stocks (MISP1 <0). Similar patterns can be found for MISP2, MISP3 and MISP4. These variables present mean values of $0.003,0.139$ and 0.093 , respectively. Their median values correspond to $0.001,0.000$ and 0.036 , respectively. The compensating effect is the result of the use of industry benchmarks to compute the measures of mispricing. Since the reference point is usually the industry mean or median, the number of overpriced and underpriced firms tends to be balanced. Thus, aggregate mispricing tends not to be too positive or too negative. In addition, the distribution of mispricing is somewhat symmetrical, which is translated in a skewness of $0.220,-0.031$ and 0.235 for MISP1, MISP2 and MISP4. Bulmer (1979) points out as a rule of thumb that a distribution with a skewness between -0.5 and 0.5 is approximately symmetric. MISP5 is the average of the standardised rankings of the absolute value of MISP1, MISP2, MISP3 and MISP4. As a result, MISP5 has two distinct properties: it indicates the level of mispricing but does not provide information regarding overpricing or underpricing; since we divide each ranking by the number of observations of the corresponding mispricing measure, each ranking cannot be lower than 0 or higher than 1. Thus, MISP5 also cannot be lower than 0 or higher than 1 because it is the average of these standardised rankings. Table 1 shows that the minimum value of MISP5 corresponds to 0.041 and its maximum to 0.995. IV_FF5 represents the main measure of IVOL which we estimate using the Fama and French (2015) five factor model. The mean (median) of IV_FF5 corresponds to 0.021 (0.019). Focusing on the UK, Angelidis and Tessaromatis (2008) find a mean value of $0.01 \overline{6}$ and Cerqueira and Pereira (2018) report a mean value of 0.023 . Overall, the mean 
value that we obtain is in line with other studies. UNVOL3 has a mean of -0.742 and a median of -2.557 . A skewness of 2.634 indicates that the tail on the right side of the distribution is longer or fatter. This is the tail that has the observations with the highest values of DIVOP, consistent with diverse levels of DIVOP within firms with higher levels of DIVOP. The observations with lower levels of DIVOP are more similar and concentrated closer to the median. This is consistent with a kurtosis of 11.843, which points out that compared to a normal distribution, there are many observations around the median.

Table 1. Descriptive statistics

\begin{tabular}{llllllll}
\hline Variables & Mean & Median & Maximum & Minimum & Std. Dev. & Skewness & Kurtosis \\
MISP1 & 0.014 & -0.004 & 2.938 & -2.488 & 0.897 & 0.220 & 4.099 \\
MISP2 & -0.003 & 0.001 & 1.915 & -1.891 & 0.700 & -0.031 & 3.262 \\
MISP3 & 0.139 & 0.000 & 5.921 & -2.430 & 1.355 & 1.538 & 7.324 \\
MISP4 & 0.093 & 0.036 & 2.985 & -2.115 & 0.885 & 0.235 & 3.418 \\
MISP5 & 0.493 & 0.475 & 0.995 & 0.041 & 0.198 & 0.259 & 2.361 \\
IV_FF5 & 0.021 & 0.019 & 0.061 & 0.002 & 0.010 & 1.272 & 4.918 \\
UNVOL3 & -0.742 & -2.557 & 30.088 & -7.394 & 5.868 & 2.634 & 11.843 \\
\hline
\end{tabular}

MISP1 is the logarithm of the ratio between market value of equity and a theoretical value (Frankel and Lee, 1998). MISP2 is the difference between the logarithm of the market value of equity and the logarithm of expected market value of equity (RhodesKropf et al., 2005). MISP3 refers to the logarithm of the ratio between firms' capital to sales ratio and the median capital to sales ratio of their corresponding industry (Berger and Ofek, 1995). MISP4 corresponds to the logarithm of the ratio of firms' marketto-book ratio and median market-to-book ratio of their corresponding industry (Walking and Edmisted, 1985; Rau and Vermaelen, 1998). MISP5 is a combination of MISP1, MISP2, MISP3 and MISP4 (Aabo et al., 2017). IV_FF5 is annual idiosyncratic volatility computed using the Fama and French (2015) five factor model. UNVOL3 refers to unexplained trading volume in the three months prior to the EPS announcement date.

Table 2 reports Pearson correlations between the main variables. All five mispricing measures show a positive correlation with each other that is statistically significant at the 99\% confidence level. Abs(MISP3) and Abs(MISP4) have the lowest correlation (0.166), while Abs(MISP2) and Abs(MISP5) (0.770) have the highest. In fact, Abs(MISP5) is highly correlated with all other mispricing measures, which is rather expected since those measures are the inputs used to compute MISP5. IV_FF5 also displays a significant and positive correlation with all mispricing measures, which hints that IVOL is associated with mispricing. A similar association has been documented for the US (Aabo et al., 2017). The last column shows a positive non-trivial correlation between UNVOL3 and IV_FF5 (0.188). Atmaz and Basak (2018) document that DIVOP leads to increased volatility and Berkman et al. (2009) use IVOL to proxy for DIVOP. Thus, a positive significant correlation between UNVOL3 and IV_FF5 is somewhat expected. The most intriguing result in Table 2 is perhaps the correlations between UNVOL3 and the mispricing measures. Although UNVOL3 is positively correlated with IV_FF5, and IV_FF5 is positively correlated with mispricing measures, UNVOL3 is negatively correlated with A bs(MISP1) (-0.049), Abs(MISP3) (-0.037) and Abs(MISP5) (-0.039), and shows no significant correlation with Abs(MISP2) (0.004) and Abs(MISP4) (0.007). There are two potential explanations for this outcome. The first one is the lack of control variables in univariate tests, especially since UNVOL3 can be rather noisy. We solve this by applying multivariate tests and by testing a large array of alternative measures of DIVOP (ABVOL; DISP1; IV_FF5) and also different time frames (UNVOL6; UNVOL9). Secondly, the association between DIVOP (UNVOL3) and mispricing may be different for overpriced and underpriced stocks. Researchers document that the associations with mispricing can be distinct for overpriced and underpriced stocks (Diether et al., 2002; Doukas et al., 2006a). To address this possibility, after testing the association between DIVOP and absolute mispricing, we apply our tests separately to overpriced and underpriced stocks. 
Table 2. Pearson correlations

\begin{tabular}{|c|c|c|c|c|c|c|}
\hline & Abs(MISP1) & Abs(MISP2) & Abs(MISP3) & Abs(MISP4) & MISP5 & IV_FF5 \\
\hline Abs(MISP2) & $\begin{array}{l}0.491 * * * \\
(42.758)\end{array}$ & & & & & \\
\hline Abs(MISP3) & $\begin{array}{l}0.258 * * * \\
(20.294)\end{array}$ & $\begin{array}{l}0.203 * * * \\
(15.739)\end{array}$ & & & & \\
\hline Abs(MISP4) & $\begin{array}{l}0.484 * * * \\
(42.015)\end{array}$ & $\begin{array}{l}0.584 * * * \\
(54.520)\end{array}$ & $\begin{array}{l}0.166^{* * * *} \\
(12.742)\end{array}$ & & & \\
\hline MISP5 & $\begin{array}{l}0.698 * * * \\
(73.941)\end{array}$ & $\begin{array}{l}0.770 * * * \\
(91.587)\end{array}$ & $\begin{array}{l}0.492 * * * \\
(42.845)\end{array}$ & $\begin{array}{l}0.735 * * * \\
(82.364)\end{array}$ & & \\
\hline IV_FF5 & $\begin{array}{l}0.231 * * * \\
(18.011)\end{array}$ & $\begin{array}{l}0.200 * * * \\
(15.486)\end{array}$ & $\begin{array}{l}0.213 * * * \\
(16.563)\end{array}$ & $\begin{array}{l}0.145^{* * *} \\
(11.108)\end{array}$ & $\begin{array}{l}0.242 * * * \\
(18.898)\end{array}$ & \\
\hline UNVOL3 & $\begin{array}{l}-0.049 * * * \\
(-3.722)\end{array}$ & $\begin{array}{l}0.004 \\
(0.323)\end{array}$ & $\begin{array}{l}-0.037 * * * \\
(-2.824)\end{array}$ & $\begin{array}{l}0.007 \\
(0.551)\end{array}$ & $\begin{array}{l}-0.039 * * * \\
(-2.991)\end{array}$ & $\begin{array}{l}0.188 * * * \\
(14.528)\end{array}$ \\
\hline
\end{tabular}

This table shows Pearson correlation coefficients and corresponding t-statistics (in brackets). $* * * * * *$ represent statistical significance with a confidence level of $90 \%, 95 \%$ and $99 \%$, respectively. MISP1 is the logarithm of the ratio between market value of equity and a theoretical value (Frankel and Lee, 1998). MISP2 is the difference between the logarithm of the market value of equity and the logarithm of expected market value of equity (Rhodes-Kropf et al., 2005). MISP3 refers to the logarithm of the ratio between firms' capital to sales ratio and the median capital to sales ratio of their corresponding industry (Berger and Ofek, 1995). MISP4 corresponds to the logarithm of the ratio of firms market-to-book ratio and median market-to-book ratio of their corresponding industry (Walking and Edmisted, 1985; Rau and Vermaelen, 1998). MISP5 is a combination of MISP1, MISP2, MISP3 and MISP4 (Aabo et al., 2017). IV_FF5 is annual idiosyncratic volatility computed using the Fama and French (2015) five factor model. UNVOL3 refers to unexplained trading volume in the three months prior to the EPS announcement date.

\section{Multivariate results}

\section{Results}

This section shows the multivariate tests. Table 3 displays the results of estimating Equation 1.12, using IV_FF5 as a proxy of DIVOP. The difference between these estimations is the dependent variable, which corresponds to each of the five different measures of mispricing. The tests point to a positive association between IV_FF5 and all measures of mispricing. This relationship is always statistically significant at the $99 \%$ confidence level. This outcome is in line with Aabo et al., (2017), who also find a robust positive association between IVOL and mispricing for the US. The authors suggest that these results reflect the increasing role of noise traders, which is consistent with the noise trading hypothesis (see, for instance, Danthine and Moresi, 1993). The amount of research on IVOL is extensive. Especially since Campbell et al. (2001) concluded that IVOL has been following a positive trend and Ang et al. (2006) pointed out that IVOL leads to lower stock returns. Many explanations have been presented for these two phenomena. As examples of explanations of the upward trend one can consider: institutional investors (Xu and Malkiel, 2003), market competition (Gaspar and Massa, 2006), new listings (Fink et al., 2010), retail investors (Brandt et al., 2009) or financial reporting quality (Rajgopal and Venkatachalam, 2011). Explanations of the association between IVOL and lower future stock returns are: small capitalisation stocks (Angelidis and Tessaromatis, 2008), liquidity risk or DIVOP (Guo and Savickas, 2008), liquidity biases (Han and Lesmond, 2011), arbitrage asymmetry (Stambaugh et al., 2015) and other limits of arbitrage (Gu et al., 2018) or macro finance factors (Aslanidis et al., 2019). In addition, IVOL has been used as a proxy for different financial phenomena, namely arbitrage risk (Doukas et al., 2010), noise trading (Aabo et al., 2017) or DIVOP (Berkman et al., 2009). Therefore, IVOL has many interpretations and many theories have been built around it. We use IVOL as an indicator of DIVOP, hence we interpret that our results point to a positive association between DIVOP (IV_FF5) and mispricing. Naturally, other interpretations exist and are not 
necessarily less coherent. In additional tests, we apply different proxies of DIVOP to assess the robustness of our interpretation.

Table 3. Regression results obtained using IV_FF5 to proxy DIVOP (Equation 1.12)

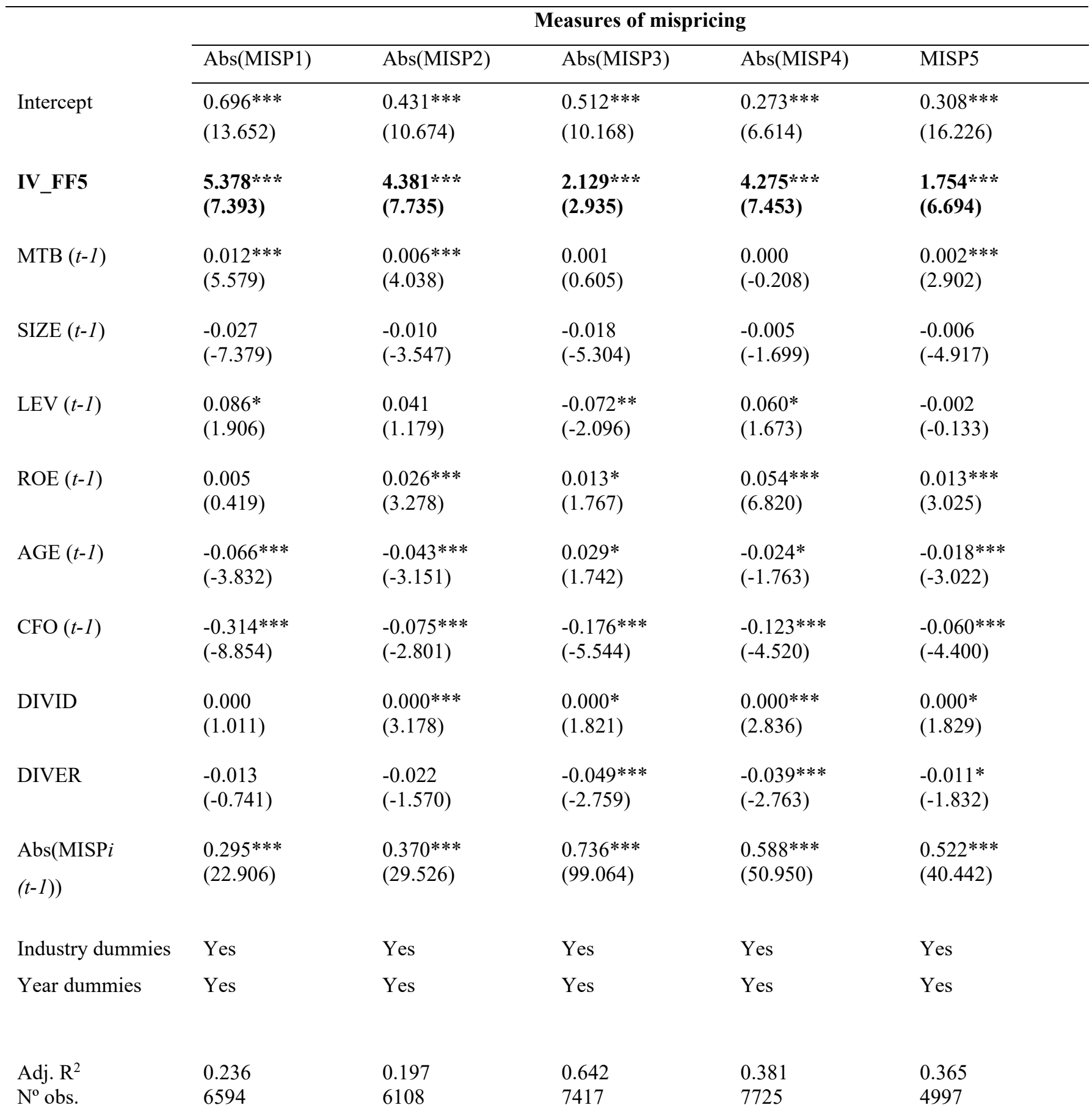

This table shows estimated coefficients and corresponding t-statistics (in brackets). * $* *$ and $* * *$ represent statistical significance with a confidence level of $90 \%, 95 \%$ and $99 \%$, respectively. The independent variables are MISP1-5. MISP1 is the logarithm of the ratio between market value of equity and a theoretical value (Frankel and Lee, 1998). MISP2 is the difference between the logarithm of the market value of equity and the logarithm of expected market value of equity (Rhodes-Kropf et al., 2005). MISP3 refers to the logarithm of the ratio between firms' capital to sales ratio and the median capital to sales ratio of their corresponding industry (Berger and Ofek, 1995). MISP4 corresponds to the logarithm of the ratio of firms' market-to-book ratio and median market-to-book ratio of their corresponding industry (Walking and Edmisted, 1985; Rau and Vermaelen, 1998). MISP5 is a combination of MISP1, MISP2, MISP3 and MISP4 (Aabo et al., 2017). IV_FF5 is annual idiosyncratic volatility computed using the Fama and French (2015) five factor model and proxies for DIVOP. MTB corresponds to market-to-book value of equity. SIZE refers to the logarithm of market value of equity. LEV is long-term debt divided by total assets. ROE corresponds to return- 
on-equity. AGE corresponds to the logarithm of firms' age in years. CFO refers to cash-flow from operations scaled by total assets. DIVID is a dummy variable that equals one if the firm pays dividends. DIVER is a dummy variable that equals one if the firm operates in more than one industry.

To compute IVOL we use the Fama and French (2015) five factor model. There are, however, alternative models that can be used to estimate IVOL. The method employed to compute IVOL may affect the results. For instance, Malagon et al. (2015) show that the IVOL puzzle dissipates when the Fama and French (2015) five factor model is used to compute IVOL. To assess whether the model used influences the outcome, we reproduce the tests disclosed in Table 3 using alternative and widely used methods. Specifically, we consider the market model (Sharpe, 1963; Fama 1973), the Fama and French (1993) three factor model and the Carhart (1997) model. As examples, the market model is applied by Dennis and Strickland (2004) and Angelidis and Tessaromatis (2008), the three factor model is employed by Ang et al. (2009) and Rajgopal and Venkatachalam (2011) and the Carhart (1997) model is used by Trimech and Kortas (2009) and Han and Lesmond (2011). Table 4 displays the results of the tests using these alternative models. For efficiency reasons, Table 4 only discloses the coefficients and t-statistics of the coefficients of the proxies of IVOL. Overall, the results show that the association between IVOL and mispricing is positive and statistically significant and this inference is robust across alternative measurements of IVOL.

Table 4. Regression results based on different measures of idiosyncratic volatility (Equation 1.12)

\begin{tabular}{lccccc}
\hline & \multicolumn{5}{c}{ Measures of mispricing } \\
\cline { 2 - 5 } & Abs(MISP1) & Abs(MISP2) & Abs(MISP3) & Abs(MISP4) & MISP5 \\
\cline { 2 - 6 } IV_MKT & $5.117 * * *$ & $4.237 * * *$ & $1.942 * * *$ & $4.018 * * *$ & $1.649 * * *$ \\
& $(7.166)$ & $(7.628)$ & $(2.733)$ & $(7.141)$ & $(6.419)$ \\
IV_FF3 & & & $1.983 * * *$ & $4.062 * * *$ & $1.665 * * *$ \\
& $(7.184 * * *$ & $4.283 * * *$ & $(2.771)$ & $(7.168)$ & $(6.433)$ \\
IV_MOM & $(7.657)$ & & & $4.085 * * *$ & $1.673 * * *$ \\
& $5.217 * * *$ & $4.301 * * *$ & $(7.193)$ & $(6.449)$ \\
\hline
\end{tabular}

We re-estimate Equation 1.12 and use alternative proxies of DIVOP based on IVOL. IV_MKT, IV_FF3 and IV_MOM correspond to annual idiosyncratic volatility computed using the market model (Sharpe, 1963; Fama, 1973), the Fama and French (1993) three factor model and the Carhart (1997) model, respectively. This table shows estimated coefficients and corresponding t-statistics (in brackets) for the proxies of DIVOP (IV_MKT, IV_FF3 and IV_MOM). *, ** and *** represent statistical significance with a confidence level of $90 \%, 95 \%$ and $99 \%$, respectively. The independent variables are MISP1-5. MISP1 is the logarithm of the ratio between market value of equity and a theoretical value (Frankel and Lee, 1998). MISP2 is the difference between the logarithm of the market value of equity and the logarithm of expected market value of equity (Rhodes-Kropf et al., 2005). MISP3 refers to the logarithm of the ratio between firms' capital to sales ratio and the median capital to sales ratio of their corresponding industry (Berger and Ofek, 1995). MISP4 corresponds to the logarithm of the ratio of firms' market-to-book ratio and median market-to-book ratio of their corresponding industry (Walking and Edmisted, 1985; Rau and Vermaelen, 1998). MISP5 is a combination of MISP1, MISP2, MISP3 and MISP4 (Aabo et al., 2017).

Following Berkman et al. (2009), we use IVOL to proxy for DIVOP. Still, IVOL may proxy for several financial phenomena, such as liquidity risk (Guo and Savickas, 2008), information risk (Jiang et al., 2009; Berrada and Hugonnier, 2013), arbitrage risk (Doukas et al., 2010) or noise trading (Aabo et al., 2017). Thus, we consider alternative and more straightforward measures of DIVOP. Our main alternative proxy of DIVOP corresponds to UNVOL 3 and refers to unexplained trading volume in the three months prior to the earnings per share announcement date. Its computation is based on the work developed by Garfinkel (2009). The author had access to proprietary limit order and market order data, allowing him to build a precise measure of DIVOP. The author then examines which of the proxies used in the literature better correlate with it, concluding that measures based on trading volume are the best proxies of DIVOP. To study the association between DIVOP and mispricing, we estimate Equation 1.12 using five different measures of mispricing as dependent variables and UNVOL3 as an independent variable, along with a set of control variables. Table 5 discloses the results. We find a positive significant association between UNVOL3 and all five measures of mispricing. 
Table 5. Regression results obtained using UNVOL3 to proxy DIVOP (Equation 1.12)

\begin{tabular}{|c|c|c|c|c|c|}
\hline & \multicolumn{5}{|c|}{ Measures of mispricing } \\
\hline & Abs(MISP1) & Abs(MISP2) & Abs(MISP3) & Abs(MISP4) & MISP5 \\
\hline Intercept & $\begin{array}{l}0.874 * * * \\
(15.726)\end{array}$ & $\begin{array}{l}0.581 * * * \\
(13.344)\end{array}$ & $\begin{array}{l}0.595 * * * \\
(10.913)\end{array}$ & $\begin{array}{l}0.429 * * * \\
(9.738)\end{array}$ & $\begin{array}{l}0.356^{* * * *} \\
(16.330)\end{array}$ \\
\hline UNVOL3 & $\begin{array}{l}0.003 * * \\
(1.987)\end{array}$ & $\begin{array}{l}0.004 * * * \\
(4.100)\end{array}$ & $\begin{array}{l}0.003 * * \\
(2.228)\end{array}$ & $\begin{array}{l}0.003 * * * \\
(2.848)\end{array}$ & $\begin{array}{l}0.001 * * \\
(2.551)\end{array}$ \\
\hline $\operatorname{MTB}(t-1)$ & $\begin{array}{l}0.014 * * * \\
(5.890)\end{array}$ & $\begin{array}{l}0.008^{* * *} \\
(4.942)\end{array}$ & $\begin{array}{c}0.000 \\
(-0.037)\end{array}$ & $\begin{array}{c}0.002 \\
(0.969)\end{array}$ & $\begin{array}{l}0.003 * * * \\
(3.456)\end{array}$ \\
\hline $\operatorname{SIZE}(t-1)$ & $\begin{array}{l}-0.030 * * * \\
(-6.933)\end{array}$ & $\begin{array}{l}-0.014 * * * \\
(-4.175)\end{array}$ & $\begin{array}{l}-0.018 * * * \\
(-4.599)\end{array}$ & $\begin{array}{l}-0.009 * * * \\
(-2.724)\end{array}$ & $\begin{array}{l}-0.007 * * * \\
(-4.455)\end{array}$ \\
\hline $\operatorname{LEV}(t-1)$ & $\begin{array}{c}0.067 \\
(1.335)\end{array}$ & $\begin{array}{c}0.011 \\
(0.290)\end{array}$ & $\begin{array}{l}-0.104 * * * \\
(-2.658)\end{array}$ & $\begin{array}{c}0.077 * \\
(1.948)\end{array}$ & $\begin{array}{c}-0.002 \\
(-0.111)\end{array}$ \\
\hline $\operatorname{ROE}(t-1)$ & $\begin{array}{c}-0.008 \\
(-0.581)\end{array}$ & $\begin{array}{l}0.028 * * * \\
(2.928)\end{array}$ & $\begin{array}{l}0.021 * * \\
(2.454)\end{array}$ & $\begin{array}{l}0.057 * * * \\
(6.085)\end{array}$ & $\begin{array}{l}0.012 * * \\
(2.502)\end{array}$ \\
\hline $\operatorname{AGE}(t-1)$ & $\begin{array}{l}-0.076 * * * \\
(-4.022)\end{array}$ & $\begin{array}{l}-0.058 * * * \\
(-3.841)\end{array}$ & $\begin{array}{c}0.026 \\
(1.433)\end{array}$ & $\begin{array}{l}-0.034^{* *} \\
(-2.219)\end{array}$ & $\begin{array}{l}-0.021 * * * \\
(-3.206)\end{array}$ \\
\hline $\mathrm{CFO}(t-1)$ & $\begin{array}{l}-0.377 * * * \\
(-9.546)\end{array}$ & $\begin{array}{l}-0.132 * * * \\
(-4.403)\end{array}$ & $\begin{array}{l}-0.213 * * * \\
(-5.955)\end{array}$ & $\begin{array}{l}-0.190 * * * \\
(-6.302)\end{array}$ & $\begin{array}{l}-0.082 * * * \\
(-5.436)\end{array}$ \\
\hline DIVID & $\begin{array}{c}0.000 \\
(0.807)\end{array}$ & $\begin{array}{l}0.000^{* * *} \\
(3.138)\end{array}$ & $\begin{array}{c}0.000 * \\
(1.820)\end{array}$ & $\begin{array}{l}0.000 * * * \\
(2.746)\end{array}$ & $\begin{array}{c}0.000 \\
(1.621)\end{array}$ \\
\hline DIVER & $\begin{array}{l}-0.043 * * \\
(-2.147)\end{array}$ & $\begin{array}{l}-0.044 * * * \\
(-2.839)\end{array}$ & $\begin{array}{l}-0.055^{* * *} \\
(-2.745)\end{array}$ & $\begin{array}{l}-0.058 * * * \\
(-3.630)\end{array}$ & $\begin{array}{l}-0.020 * * * \\
(-2.892)\end{array}$ \\
\hline $\begin{array}{l}\text { Abs(MISP } i \\
(t-1))\end{array}$ & $\begin{array}{l}0.287 * * * \\
(20.107)\end{array}$ & $\begin{array}{l}0.371 * * * \\
(26.957)\end{array}$ & $\begin{array}{l}0.738 * * * \\
(89.538)\end{array}$ & $\begin{array}{l}0.584 * * * \\
(45.361)\end{array}$ & $\begin{array}{l}0.526 * * * \\
(36.769)\end{array}$ \\
\hline \multicolumn{6}{|c|}{ Industry dummies } \\
\hline Year dummies & $\begin{array}{l}\text { Yes } \\
\text { Yes }\end{array}$ & $\begin{array}{l}\text { Yes } \\
\text { Yes }\end{array}$ & $\begin{array}{l}\text { Yes } \\
\text { Yes }\end{array}$ & $\begin{array}{l}\text { Yes } \\
\text { Yes }\end{array}$ & $\begin{array}{l}\text { Yes } \\
\text { Yes }\end{array}$ \\
\hline Adj. $\mathrm{R}^{2}$ & 0.229 & 0.197 & 0.644 & 0.383 & 0.361 \\
\hline $\mathrm{N}^{\mathrm{o}}$ obs. & 5402 & 5033 & 6097 & 6364 & 4103 \\
\hline
\end{tabular}

This table shows estimated coefficients and corresponding t-statistics (in brackets). *,** and *** represent statistical significance with a confidence level of $90 \%, 95 \%$ and $99 \%$, respectively. The independent variables are MISP1-5. MISP1 is the logarithm of the ratio between market value of equity and a theoretical value (Frankel and Lee, 1998). MISP2 is the difference between the logarithm of the market value of equity and the logarithm of expected market value of equity (Rhodes-Kropf et al., 2005). MISP3 refers to the logarithm of the ratio between firms' capital to sales ratio and the median capital to sales ratio of their corresponding industry (Berger and Ofek, 1995). MISP4 corresponds to the logarithm of the ratio of firms' market-to-book ratio and median market-to-book ratio of their corresponding industry (Walking and Edmisted, 1985; Rau and Vermaelen, 1998). MISP5 is a combination of MISP1, MISP2, MISP3 and MISP4 (Aabo et al., 2017). UNVOL3 is unexplained trading volume in the three months prior to the EPS announcement date and proxies for DIVOP. MTB corresponds to market-to-book value of equity. SIZE refers to the logarithm of market value of equity. LEV is long-term debt divided by total assets. ROE corresponds to return-onequity. AGE corresponds to the logarithm of firms' age in years. CFO refers to cash-flow from operations scaled by total assets. DIVID is a dummy variable that equals one if the firm pays dividends. DIVER is a dummy variable that equals one if the firm operates in more than one industry.

To better gauge the association between DIVOP and mispricing, we extend the measure of unexplained trading volume by computing UNVOL6 and UNVOL9. These measures capture unexplained trading volume in the six and nine months prior to the earnings announcement date, respectively. Table 6 displays the results. Using these measures to proxy for DIVOP, we still find a positive and significant relationship.

We lengthen the reliability of the tests by including other proxies of DIVOP. Following Garfinkel (2009), we compute ABVOL3, which refers to abnormal trading volume in the three months prior to the earnings announcement 
date. It corresponds to stock turnover adjusted by both stock's historic trading volume and market trading volume. We find a positive association between ABVOL3 and four of the five mispricing measures, albeit we only have slightly significant coefficients in two cases. In additional tests (disclosed in Table 10), we show that ABVOL3 has a positive significant association with mispricing for underpriced stocks and no significant association for overpriced stocks. When mix overpriced and underpriced stocks we get barely or non-significant coefficients.

Finally, we use DISP made one year ahead (DISP1 in Table 6) to proxy DIVOP. This is likely the most used proxy in the literature (Diether et al., 2002; Chen et al., 2002; Berkman et al., 2009; Chatterjee et al., 2012). The coefficients of DISP 1 are positive and tend to be statistically significant.

Taken together, the results of the tests point out to a robust relationship between DIVOP and mispricing. It does not matter if we use a proxy based on IVOL (IV_MKT, IV,FF3, IV_MOM or IV_FF5), unexpected trading volume (UNVOL3, UNVOL6, UNVOL9, ABVOL3) or DISP (DISP1), the tests show a positive association between DIVOP and stock mispricing.

Table 6. Regression results obtained using different measures of DIVOP (Equation 1.12)

\begin{tabular}{lccccc}
\hline & \multicolumn{5}{c}{ Measures of mispricing } \\
\cline { 2 - 5 } UNVOL6 & Abs(MISP1) & Abs(MISP2) & Abs(MISP3) & Abs(MISP4) & MISP5 \\
\cline { 2 - 5 } & 0.002 & $0.004^{* * *}$ & $0.004^{* *}$ & $0.002^{*}$ & $0.001^{*}$ \\
UNVOL9 & $(1.511)$ & $(3.847)$ & $(2.425)$ & $(1.667)$ & $(1.853)$ \\
& $0.002^{*}$ & $0.005^{* * *}$ & $0.004^{* *}$ & $0.002^{* *}$ & $0.001^{* *}$ \\
ABVOL3 & $(1.649)$ & $(4.096)$ & $(2.446)$ & $(1.973)$ & $(1.989)$ \\
& 0.002 & $0.002^{*}$ & -0.001 & $0.002^{*}$ & 0.000 \\
DISP1*100 & $(1.430)$ & $(1.868)$ & $(-0.423)$ & $(1.851)$ & $(0.683)$ \\
& $0.094^{* * *}$ & $0.047^{* *}$ & $0.035^{*}$ & 0.013 & $0.024^{* *}$ \\
& $(3.379)$ & $(2.387)$ & $(1.925)$ & $(0.683)$ & $(2.528)$ \\
\hline
\end{tabular}

We re-estimate Equation 1.12 and use alternative proxies of DIVOP, namely UNVOL6, UNVOL9, ABVOL3 and DISP1. This table shows estimated coefficients and corresponding t-statistics (in brackets) for the proxies of DIVOP (UNVOL6; UNVOL9; ABVOL3; DISP1). *, ** and *** represent statistical significance with a confidence level of $90 \%, 95 \%$ and $99 \%$, respectively. UNVOL6 is unexplained trading volume in the six months prior to the EPS announcement date. UNVOL9 is unexplained trading volume in the nine months prior to the EPS announcement date. ABVOL3 is abnormal trading volume in the three months prior to the EPS announcement date. DISP1 refers to dispersion in analysts' forecast made one year ahead. The independent variables are MISP1-5. MISP1 is the logarithm of the ratio between market value of equity and a theoretical value (Frankel and Lee, 1998). MISP2 is the difference between the logarithm of the market value of equity and the logarithm of expected market value of equity (Rhodes-Kropf et al., 2005). MISP3 refers to the logarithm of the ratio between firms' capital to sales ratio and the median capital to sales ratio of their corresponding industry (Berger and Ofek, 1995). MISP4 corresponds to the logarithm of the ratio of firms' market-to-book ratio and median market-to-book ratio of their corresponding industry (Walking and Edmisted, 1985; Rau and Vermaelen, 1998). MISP5 is a combination of MISP1, MISP2, MISP3 and MISP4 (Aabo et al., 2017).

\section{Sensitivity tests}

Table 7 and Table 8 display additional tests applied with the purpose of evaluating the robustness of the association between DIVOP and mispricing. Table 7 shows the coefficients of IV_FF5 obtained using different estimation methods. In our baseline test, we include industry dummies and time fixed effects. As a robustness test, we employ firm fixed effects to assess the impact of cross-sectional heterogeneity. The coefficients obtained are positive and statistically significant in four of the five regressions. This implies that heterogeneity does not meaningfully affect the outcome. To account for heteroscedasticity, we use two different approaches. In both cases we apply the generalised least squares method, but we use cross-section weights in one estimation and period weights in the other. This allows us to separately test the influence of heteroscedasticity in the cross-section and in the time series. Independently of the measure of mispricing, we obtain positive and significant coefficients in both tests. Hence, there is no evidence that heteroscedasticity biases the analysis. A caveat of the tests disclosed in Table 2 is the high tstatistics of $\mathrm{Abs}\left(\mathrm{MISP}_{i, t-1}\right)$. This suggests that there is high positive serial correlation. In terms of economic interpretation, it hints that mispriced stocks tend to stay mispriced. This suggests that there may be some market frictions, but it does not imply that prices do not tend to equilibrium in the long-run. These tests consider absolute mispricing, that is underpricing and overpricing are not distinguished. Thus, a stock can be underpriced in one year and slightly overpriced the following year, due to mean reversion (market efficiency) combined with overreaction 
(market friction) (De Bondt and Thaler, 1985). To deal with the effects of serial correlation, we apply period seemingly unrelated regressions, which control for both serial correlation between the residuals of a given crosssection and heteroscedasticity. This procedure does not change in any way the conclusions obtained from the baseline tests presented in Table 2. Another issue that we consider is the potential impact of outliers. As shown in the methodology, we windsorise all the variables at the first and last percentile, which is a common procedure in the literature. In additional tests (disclosed in Table 7), we estimate the regressions using the robust least squares method. We find a positive and significant association between IV_FF5 and mispricing in four out of five tests. Finally, we account for the possible effect of new listings and exits. Fink et al. (2010) show that the increase in IVOL in the nineties came from new listings of relatively younger firms, which may have led to the findings of Campbell et al. (2001) that IVOL had been following an upward trend. We reproduce the tests while considering only firms with at least ten observations and find no relevant changes in the coefficients. Overall, our findings indicate a positive and robust association between IVOL and mispricing.

Table 7. Sensitivity tests on the association between IV_FF5 and mispricing (Equation 1.12)

\begin{tabular}{|c|c|c|c|c|c|}
\hline \multirow[b]{3}{*}{ Firm fixed effects } & \multicolumn{5}{|c|}{ Measures of mispricing } \\
\hline & Abs(MISP1) & Abs(MISP2) & Abs(MISP3) & Abs(MISP4) & MISP5 \\
\hline & $\begin{array}{l}5.424^{* * *} \\
(3.635)\end{array}$ & $\begin{array}{l}7.202^{* * *} \\
(6.801)\end{array}$ & $\begin{array}{c}1.164 \\
(0.886)\end{array}$ & $\begin{array}{l}6.777 * * * \\
(6.407)\end{array}$ & $\begin{array}{l}2.779 * * * \\
(6.056)\end{array}$ \\
\hline $\begin{array}{l}\text { GLS cross section } \\
\text { weights }\end{array}$ & $\begin{array}{l}3.342 * * * \\
(9.099)\end{array}$ & $\begin{array}{l}4.765^{* * *} \\
(13.737)\end{array}$ & $\begin{array}{l}1.174 * * * \\
(4.074)\end{array}$ & $\begin{array}{l}5.095 * * * \\
(16.355)\end{array}$ & $\begin{array}{l}2.115 * * * \\
(13.344)\end{array}$ \\
\hline $\begin{array}{l}\text { GLS period } \\
\text { weights }\end{array}$ & $\begin{array}{l}6.161 * * * \\
(7.677)\end{array}$ & $\begin{array}{l}5.112 * * * \\
(8.762)\end{array}$ & $\begin{array}{l}2.316^{* * * *} \\
(3.045)\end{array}$ & $\begin{array}{l}5.246^{* * *} \\
(8.585)\end{array}$ & $\begin{array}{l}1.887 * * * \\
(7.420)\end{array}$ \\
\hline $\begin{array}{l}\text { Period seemingly } \\
\text { unrelated } \\
\text { regressions }\end{array}$ & $\begin{array}{l}6.127 * * * \\
(7.604)\end{array}$ & $\begin{array}{l}5.090^{* * *} \\
(8.675)\end{array}$ & $\begin{array}{l}2.168 * * * \\
(2.950)\end{array}$ & $\begin{array}{l}5.012 * * * \\
(8.136)\end{array}$ & $\begin{array}{l}1.879 * * * \\
(7.496)\end{array}$ \\
\hline $\begin{array}{l}\text { Robust least } \\
\text { squares }\end{array}$ & $\begin{array}{l}4.164 * * * \\
(7.050)\end{array}$ & $\begin{array}{l}3.473^{* * *} \\
(6.585)\end{array}$ & $\begin{array}{c}0.667 \\
(1.402)\end{array}$ & $\begin{array}{l}2.638^{* * * *} \\
(5.411)\end{array}$ & $\begin{array}{l}1.956^{* * * *} \\
(7.531)\end{array}$ \\
\hline $\begin{array}{l}\text { Limiting new } \\
\text { listings and exits }\end{array}$ & $\begin{array}{l}6.340 * * * \\
(6.669)\end{array}$ & $\begin{array}{l}4.204 * * * \\
(6.132)\end{array}$ & $\begin{array}{l}2.239 * * \\
(2.376)\end{array}$ & $\begin{array}{l}5.361 * * * \\
(7.763)\end{array}$ & $\begin{array}{l}1.990 * * * \\
(6.515)\end{array}$ \\
\hline
\end{tabular}

We re-estimate Equation 1.12. The proxy of DIVOP is IV_FF5 which corresponds to annual idiosyncratic volatility computed using the Fama and French (2015) five factor model. This table shows the coefficients and t-statistics (in brackets) of IV_FF5 that are obtained using different estimation methods and assumptions (firm fixed effects; generalised least squares; period seemingly unrelated regressions; robust least squares; limiting new listing and exits). *, ** and *** represent statistical significance with a confidence level of $90 \%, 95 \%$ and $99 \%$, respectively. The independent variables are MISP1-5. MISP1 is the logarithm of the ratio between market value of equity and a theoretical value (Frankel and Lee, 1998). MISP2 is the difference between the logarithm of the market value of equity and the logarithm of expected market value of equity (Rhodes-Kropf et al., 2005). MISP3 refers to the logarithm of the ratio between firms' capital to sales ratio and the median capital to sales ratio of their corresponding industry (Berger and Ofek, 1995). MISP4 corresponds to the logarithm of the ratio of firms' market-to-book ratio and median market-to-book ratio of their corresponding industry (Walking and Edmisted, 1985; Rau and Vermaelen, 1998). MISP5 is a combination of MISP1, MISP2, MISP3 and MISP4 (Aabo et al., 2017).

We address whether and to what extent the association between UNVOL3 and mispricing is affected by econometric issues. Similar to the robustness checks on the relation between IV_FF5 and mispricing, we focus on firm level heterogeneity, heteroscedasticity, serial correlation, outliers and new listings and exits. Table 8 displays the results. For efficiency reasons, we only disclose the coefficient of UNVOL3 (DIVOP), which is the matter of interest in this analysis. We start by estimating Equation 1.12 while applying firm fixed effects. We obtain three positive coefficients out of five and one of these three is statistically significant. This outcome suggests that both UNVOL 3 and the measures of mispricing show some stability in the cross-section. In other words, the extent to which investors disagree about the pricing of a stock tends to be stable across time, indicating that the factors that boost DIVOP tend to be structural. A good example is firms' age. Older firms have a greater history in terms of operational performance that investors can consider to construct their beliefs, which reduces uncertainty and limits DIVOP (Berkman et al., 2009). An increase of one year in the age of a firm with more than twenty years of existence is not 
expected to be meaningful in terms of uncertainty. Thus, older firms are expected to show both lower and stable levels of DIVOP. Also, Fink et al. (2010) show that high IVOL in the nineties was the outcome of new listings of younger firms, increasing uncertainty and, thus, the risk that investors face. We assess the impact of heteroscedasticity in the cross-section and in the time series separately. With that purpose, we estimate Equation 1.12 using the generalised least squares method with cross-section weights and with period weights, respectively. We find a positive significant association between UNVOL3 and all five measures of mispricing, for both methods, when accounting for heteroscedasticity.

In our tests, we always include an independent variable that equals the dependent variable but lagged by one year. In other words, since the dependent variables are always a measure of mispricing, we always include mispricing in the previous year as a control variable. This allows to soften a potential bias driven by serial correlation. Indeed, we find the t-statistic of this variable to be higher than many of the other variables t-statistics. We employ period seemingly unrelated regressions to control for both serial correlation between the residuals of a given cross-section and heteroscedasticity. We find no relevant changes in the results. We also control for the potential impact of outliers albeit all the variables are windsorised at the first and last percentile. The coefficient of UNVOL3 remains positive in all five tests and sustains statistical significance in three of them. Finally, we reproduce the tests but consider only firms with at least ten observations to evaluate whether new listings or exits could be driving the results. The conclusions are in line with the previous tests.

Table 8. Sensitivity tests on the association between UNVOL3 and mispricing (Equation 1.12)

\begin{tabular}{|c|c|c|c|c|c|}
\hline \multirow[b]{3}{*}{ Firm fixed effects } & \multicolumn{5}{|c|}{ Measures of mispricing } \\
\hline & Abs(MISP1) & Abs(MISP2) & Abs(MISP3) & Abs(MISP4) & MISP5 \\
\hline & $\begin{array}{c}-0.001 \\
(-0.640)\end{array}$ & $\begin{array}{l}0.003 * * \\
(2.139)\end{array}$ & $\begin{array}{c}0.001 \\
(0.472)\end{array}$ & $\begin{array}{c}0.001 \\
(0.491)\end{array}$ & $\begin{array}{c}-0.001 \\
(-0.951)\end{array}$ \\
\hline $\begin{array}{l}\text { GLS cross section } \\
\text { weights }\end{array}$ & $\begin{array}{l}0.004^{* * *} \\
(5.738)\end{array}$ & $\begin{array}{l}0.004^{* * * *} \\
(6.588)\end{array}$ & $\begin{array}{l}0.002 * * * \\
(3.103)\end{array}$ & $\begin{array}{l}0.002 * * * \\
(2.821)\end{array}$ & $\begin{array}{l}0.002 * * * \\
(4.562)\end{array}$ \\
\hline $\begin{array}{l}\text { GLS period } \\
\text { weights }\end{array}$ & $\begin{array}{l}0.004^{* * * *} \\
(2.964)\end{array}$ & $\begin{array}{l}0.005^{* * *} \\
(4.709)\end{array}$ & $\begin{array}{l}0.003^{* *} \\
(2.085)\end{array}$ & $\begin{array}{l}0.005 * * * \\
(4.453)\end{array}$ & $\begin{array}{l}0.002 * * * \\
(3.284)\end{array}$ \\
\hline $\begin{array}{l}\text { Period seemingly } \\
\text { unrelated } \\
\text { regressions }\end{array}$ & $\begin{array}{l}0.004 * * * \\
(2.856)\end{array}$ & $\begin{array}{l}0.005^{* * *} \\
(4.511)\end{array}$ & $\begin{array}{l}0.003 * * \\
(2.192)\end{array}$ & $\begin{array}{l}0.005 * * * \\
(3.931)\end{array}$ & $\begin{array}{l}0.001 * * * \\
(3.052)\end{array}$ \\
\hline $\begin{array}{l}\text { Robust least } \\
\text { squares }\end{array}$ & $\begin{array}{c}0.002 \\
(1.399)\end{array}$ & $\begin{array}{l}0.003^{* * *} \\
(3.085)\end{array}$ & $\begin{array}{c}0.001 \\
(1.325)\end{array}$ & $\begin{array}{c}0.002 * \\
(1.690)\end{array}$ & $\begin{array}{l}0.002 * * * \\
(3.581)\end{array}$ \\
\hline $\begin{array}{l}\text { Limiting new } \\
\text { listings and exits }\end{array}$ & $\begin{array}{l}0.005^{* * *} \\
(2.954)\end{array}$ & $\begin{array}{l}0.005^{* * *} \\
(4.324)\end{array}$ & $\begin{array}{c}0.002 \\
(1.373)\end{array}$ & $\begin{array}{l}0.006^{* * *} \\
(4.596)\end{array}$ & $\begin{array}{l}0.002 * * * \\
(2.779)\end{array}$ \\
\hline
\end{tabular}

We re-estimate Equation 1.12. The proxy of DIVOP is UNVOL3 which corresponds to unexplained trading volume in the three months prior to EPS announcement date. This table shows the coefficients and t-statistics (in brackets) of UNVOL3 that are obtained using different estimation methods and assumptions (firm fixed effects; generalised least squares; period seemingly unrelated regressions; robust least squares; limiting new listing and exits). *, ** and *** represent statistical significance with a confidence level of $90 \%, 95 \%$ and $99 \%$, respectively. The independent variables are MISP1-5. MISP1 is the logarithm of the ratio between market value of equity and a theoretical value (Frankel and Lee, 1998). MISP2 is the difference between the logarithm of the market value of equity and the logarithm of expected market value of equity (Rhodes-Kropf et al., 2005). MISP3 refers to the logarithm of the ratio between firms' capital to sales ratio and the median capital to sales ratio of their corresponding industry (Berger and Ofek, 1995). MISP4 corresponds to the logarithm of the ratio of firms' market-to-book ratio and median market-to-book ratio of their corresponding industry (Walking and Edmisted, 1985; Rau and Vermaelen, 1998). MISP5 is a combination of MISP1, MISP2, MISP3 and MISP4 (Aabo et al., 2017).

\section{Overpriced versus underpriced stocks}

Ang et al. (2006) show that IVOL predicts lower future stock returns in the next month, which became known as the IVOL puzzle. Still, the IVOL puzzle holds for overpriced but not for underpriced stocks. The effect of overpriced stocks is stronger due to short-selling constraints and because there is greater arbitrage capital in long positions 
(Stambaugh et al., 2015). The evidence provided by Aabo et al., (2017) suggests that the association between IVOL and mispricing is stronger for overpriced stocks. If one considers IVOL as a proxy of DIVOP, then these results are in line with Miller's (1977) hypothesis that the market overweighs optimist valuations when there is DIVOP, due to short-sale constraints. Empirical evidence of Miller's (1977) hypothesis has been provided by Diether et al. (2002) and Berkman et al. (2009).

There is, however, opposing evidence. Broad literature suggests that IVOL and other proxies of DIVOP tend to be associated with information risk (Jiang et al., 2009; Rajgopal and Venkatachalam, 2011; Berrada and Hugonnier, 2013). According to Merton (1987), information risk should be priced. In fact, Andersen et al. (2005) show that DIVOP is priced as an information risk factor. Thus, when DIVOP is high, investors may consider higher discount rates when computing the present value of future cash-flows (or demand higher returns), which may translate in underpricing. Doukas et al. (2006a, 2006b) provide evidence consistent with DIVOP leading to underpricing.

We reproduce the baseline tests, but assess the association between IVOL and mispricing separately for underpriced and overpriced stocks. IV_FF5 is used as an independent variable along with a set of control variables. The dependent variables are the measures of mispricing, except MISP5. It corresponds to an index of the rank of the absolute value of the other mispricing measures. Hence, when it comes to MISP5 we cannot separate underpriced from overpriced stocks. Table 9 displays the coefficient of IV_FF5 for underpriced and overpriced stocks. It also discloses the difference between the coefficients. With no additional criteria, we find that the coefficient is higher for underpriced stocks for all four measures of mispricing and that the difference is statistically significant for three out of the four measures. This is consistent with IVOL, which may proxy for DIVOP, being a risk factor (Merton, 1987; Andersen et al., 2005).

We apply an additional criteria by considering the ranks of the absolute value of each mispricing measure. This allows us to check if the results are not the outcome of the specific distribution of each mispricing measure. The conclusions are the same as in the case that no criteria is applied.

We then consider only firm-years in which the mispricing level is above the median. Thus, only the highest mispriced stocks are included in the analysis. This is a way of making sure that it is not the less mispriced stocks driving the results and that the conclusions hold for stocks that are highly mispriced, being those the ones that generate more concern. The coefficient of IV_FF5 is higher for underpriced for three of the four measures of mispricing. The difference is statistically significant in all these three cases.

Qu et al. (2003) point out that the pricing of DIVOP as an information risk factor is more noticeable for small firms. Therefore, we apply the tests, but only for observations that show a SIZE below the median. We catch an interesting pattern. Even though the tests so far indicate a stronger association between IVOL and mispricing for underpriced stocks, we keep finding positive and statistically significant coefficients for IV_FF5 when we focus on overpriced stocks. However, when we focus on small firms, the association between IVOL and mispricing dissipates for overpriced stocks. For these stocks, we obtain two positive and two negative coefficients, while none of them is statistically significant. For underpriced stocks, we find a positive and significant association between IVOL and all four measures of mispricing.

Aabo et al. (2017) exclude from their analysis firms whose market value is too low, in order to avoid distorted mispricing measures due to noisy ratios. We apply a similar criteria by excluding firms when their market value is less than $€ 50$ million. The results do not change meaningfully. Overall, we find that the association between IVOL and mispricing is stronger for underpriced stocks and that the difference is more noticeable for small firms. Theoretically, this is consistent with DIVOP being priced as a risk factor. An important reminder is that our analysis relies on yearly data. These associations may be different for different horizons.

Overall, the results obtained are consistent with the underpricing hypothesis and in line with Merton (1987). Indeed, most of the empirical research that exists points to the overpricing hypothesis, but these evidences tends to be short-term focused. Recent, research has shown that these empirical findings only hold for very specific contexts (Al-Nasseri and Ali, 2018; Veenman and Verwijmeren, 2020). 
Table 9. IV_FF5's coefficients for underpriced and overpriced stocks (Equation 1.12)

\begin{tabular}{|c|c|c|c|c|c|}
\hline \multirow[b]{3}{*}{ No criteria } & \multirow[b]{3}{*}{ Underpriced } & \multicolumn{3}{|c|}{ Measures of mispricing } & \multirow[b]{2}{*}{ Abs(MISP4) } \\
\hline & & Abs(MISP1) & Abs(MISP2) & Abs(MISP3) & \\
\hline & & $\begin{array}{l}5.728 * * * \\
(5.679)\end{array}$ & $\begin{array}{l}6.407 * * * \\
(8.569)\end{array}$ & $\begin{array}{l}2.621^{* * * *} \\
(3.411)\end{array}$ & $\begin{array}{l}6.466 * * * \\
(9.168)\end{array}$ \\
\hline \multirow{5}{*}{$\begin{array}{l}\mathrm{Abs}(\mathrm{MISP} i) \text { is } \\
\text { ranked (instead of } \\
\text { absolute values) }\end{array}$} & Overpriced & $\begin{array}{l}4.933 * * * \\
(4.818)\end{array}$ & $\begin{array}{l}3.184 * * * \\
(3.833)\end{array}$ & $\begin{array}{l}1.494 * * * \\
(1.174)\end{array}$ & $\begin{array}{l}2.875^{* * *} \\
(3.167)\end{array}$ \\
\hline & Difference & $\begin{array}{c}0.795 \\
(0.446)\end{array}$ & $\begin{array}{l}3.223 * * * \\
(4.311)\end{array}$ & $\begin{array}{c}1.127 * \\
(1.883)\end{array}$ & $\begin{array}{l}3.592 * * * \\
(5.091)\end{array}$ \\
\hline & Underpriced & $\begin{array}{l}2.833^{* * *} \\
(5.600)\end{array}$ & $\begin{array}{l}3.650 * * * \\
(7.587)\end{array}$ & $\begin{array}{l}0.981 * * * \\
(2.907)\end{array}$ & $\begin{array}{l}2.943 * * * \\
(7.778)\end{array}$ \\
\hline & Overpriced & $\begin{array}{l}2.225^{* * *} \\
(4.648)\end{array}$ & $\begin{array}{l}2.113^{* * *} \\
(3.902)\end{array}$ & $\begin{array}{c}0.593 * \\
(1.702)\end{array}$ & $\begin{array}{l}1.657 * * * \\
(3.995)\end{array}$ \\
\hline & Difference & $\begin{array}{c}0.608 \\
(1.202)\end{array}$ & $\begin{array}{l}1.536^{* * *} \\
(3.194)\end{array}$ & $\begin{array}{l}0.388^{* * * *} \\
(1.150)\end{array}$ & $\begin{array}{l}1.286^{* * *} \\
(3.399)\end{array}$ \\
\hline \multirow{3}{*}{$\begin{array}{c}\text { Abs(MISP } i)> \\
\text { median } \\
\text { (Only highly } \\
\text { mispriced stocks) }\end{array}$} & Underpriced & $\begin{array}{l}4.630 * * * \\
(3.682)\end{array}$ & $\begin{array}{l}5.656^{* * *} \\
(6.611)\end{array}$ & $\begin{array}{l}3.440 * * * \\
(3.968)\end{array}$ & $\begin{array}{l}6.969 * * * \\
(8.319)\end{array}$ \\
\hline & Overpriced & $\begin{array}{l}4.749 * * * \\
(3.379)\end{array}$ & $\begin{array}{l}2.536^{* * *} \\
(2.463)\end{array}$ & $\begin{array}{c}1.308 \\
(0.650)\end{array}$ & $\begin{array}{l}2.371 * * \\
(1.996)\end{array}$ \\
\hline & Difference & $\begin{array}{l}-0.119 \\
(0.120)\end{array}$ & $\begin{array}{l}3.120 * * * \\
(3.647)\end{array}$ & $\begin{array}{l}2.132^{* *} \\
(2.459)\end{array}$ & $\begin{array}{l}4.598 * * * \\
(5.489)\end{array}$ \\
\hline \multirow{3}{*}{$\begin{array}{c}\text { SIZE }<\text { median } \\
\text { (only smallest } \\
\text { firms) }\end{array}$} & Underpriced & $\begin{array}{l}5.154 * * * \\
(4.068)\end{array}$ & $\begin{array}{l}5.955^{* * *} \\
(6.128)\end{array}$ & $\begin{array}{l}2.251 * * \\
(2.232)\end{array}$ & $\begin{array}{l}6.384 * * * \\
(7.320)\end{array}$ \\
\hline & Overpriced & $\begin{array}{c}1.055 \\
(0.688)\end{array}$ & $\begin{array}{c}-0.593 \\
(-0.507)\end{array}$ & $\begin{array}{c}-1.443 \\
(-0.633)\end{array}$ & $\begin{array}{c}0.006 \\
(0.004)\end{array}$ \\
\hline & Difference & $\begin{array}{l}4.099 * * * \\
(3.235)\end{array}$ & $\begin{array}{l}6.548^{* * *} \\
(6.738)\end{array}$ & $\begin{array}{l}3.694 * * * \\
(3.662)\end{array}$ & $\begin{array}{l}6.378^{* * *} \\
(7.313)\end{array}$ \\
\hline \multirow{3}{*}{$\begin{array}{l}\text { Market value }> \\
50 \mathrm{M} \\
\text { (Excludes micro } \\
\text { firms that may } \\
\text { have noisy ratios) }\end{array}$} & Underpriced & $\begin{array}{l}12.065^{* * *} \\
(6.660)\end{array}$ & $\begin{array}{l}11.444 * * * \\
(9.234)\end{array}$ & $\begin{array}{l}4.483 * * * \\
(3.603)\end{array}$ & $\begin{array}{l}10.377 * * * \\
(8.438)\end{array}$ \\
\hline & Overpriced & $\begin{array}{l}11.220 * * * \\
(7.174)\end{array}$ & $\begin{array}{l}6.608^{* * *} \\
(5.108)\end{array}$ & $\begin{array}{c}1.095 \\
(0.721)\end{array}$ & $\begin{array}{l}3.635^{* * *} \\
(2.845)\end{array}$ \\
\hline & Difference & $\begin{array}{c}0.846 \\
(0.467)\end{array}$ & $\begin{array}{l}4.836^{* * *} \\
(3.902)\end{array}$ & $\begin{array}{l}3.388^{* * * *} \\
(2.723)\end{array}$ & $\begin{array}{l}6.742 * * * \\
(5.482)\end{array}$ \\
\hline
\end{tabular}

We re-estimate Equation 1.12 separately for underpriced and overpriced stocks. The proxy of DIVOP is IV_FF5 which corresponds to annual idiosyncratic volatility computed using the Fama and French (2015) five factor model. This table shows the coefficients and t-statistics (in brackets) of IV_FF5 that are obtained for underpriced and overpriced stocks. We also compute de difference between the coefficient estimated for underpriced and overpriced stocks. Below this difference we show in brackets a t-statistic of a test in which the null hypothesis is that the difference is zero. * $* *$ and $* * *$ represent statistical significance with a confidence level of $90 \%, 95 \%$ and $99 \%$, respectively. The independent variables are MISP1-5. MISP1 is the logarithm of the ratio between market value of equity and a theoretical value (Frankel and Lee, 1998). MISP2 is the difference between the logarithm of the market value of equity and the logarithm of expected market value of equity (Rhodes-Kropf et al., 2005). MISP3 refers to the logarithm of the ratio between firms' capital to sales ratio and the median capital to sales ratio of their corresponding industry (Berger and Ofek, 1995). MISP4 corresponds to the logarithm of the ratio of firms' market-to-book ratio and median market-to-book ratio of their corresponding industry (Walking and Edmisted, 1985; Rau and Vermaelen, 1998).

Again, we study the association between DIVOP and mispricing separately for underpriced and overpriced stocks, but the proxies of DIVOP that we use are UNVOL3, UNVOL6, UNVOL9, ABVOL3 and DISP1. Table 10 presents the results. We disclose both the coefficients and t-statistics for each measure of DIVOP. Also, for each proxy of DIVOP, we compute the difference between the coefficient estimated for underpriced and overpriced stocks along with a t-statistic of a statistical test whose null hypothesis is that the coefficients are equal. We find that the association between UNVOL3 and mispricing is stronger for underpriced in three of the four tests and this difference is statistically significant in one of those cases. We find similar patterns when we proxy DIVOP through UNVOL6 and 
UNVOL9. The tests that use MISP3 as dependent variable are the only ones who point out to a stronger relation for overpriced stocks. In Table 8 we show that, even though we find a positive association between ABVOL3 and mispricing, it is the weakest association compared to the relation between the other proxies of DIVOP and mispricing. The results displayed in Table 10 suggest that this happens because in those tests we mix underpriced with overpriced stocks. It appears that the association between ABVOL3 and mispricing is positive and robust for underpriced stocks, but almost inexistent for overpriced stocks. In three out of the four tests, the coefficient obtained for underpriced stocks is statistically different from the one estimated for overpriced stocks. Finally, we use DISP1 to measure DIVOP. Similar to the previous measures of DIVOP, we tend to find a stronger association between DISP1 and mispricing for underpriced stocks.

Taken together all the different proxies of DIVOP, the results hint that the relationship between DIVOP and mispricing is stronger for underpriced stocks than for overpriced stocks. The difference between underpriced and overpriced stocks is very noticeable when we focus on small firms. The results are show a more pronounced difference between underpriced and overpriced stocks when we proxy DIVOP through IVOL. A likely explanation is that IVOL incorporates other idiosyncratic risks that go beyond DIVOP.

Table 10. Coefficients of different proxies of DIVOP for underpriced and overpriced stocks

\begin{tabular}{|c|c|c|c|c|c|}
\hline & \multicolumn{5}{|c|}{ Measures of mispricing } \\
\hline & & Abs(MISP1) & Abs(MISP2) & Abs(MISP3) & Abs(MISP4) \\
\hline \multirow[t]{3}{*}{ UNVOL3 } & Underpriced & $\begin{array}{l}0.004^{* *} \\
(2.427)\end{array}$ & $\begin{array}{l}0.006 * * * \\
(4.186)\end{array}$ & $\begin{array}{c}0.002 \\
(1.206)\end{array}$ & $\begin{array}{l}0.004^{* * * *} \\
(3.314)\end{array}$ \\
\hline & Overpriced & $\begin{array}{c}0.002 \\
(0.916)\end{array}$ & $\begin{array}{c}0.003 * \\
(1.832)\end{array}$ & $\begin{array}{c}0.004 * \\
(1.863)\end{array}$ & $\begin{array}{c}0.002 \\
(1.345)\end{array}$ \\
\hline & Difference & $\begin{array}{c}0.003 \\
(1.478)\end{array}$ & $\begin{array}{l}0.003^{* *} \\
(2.182)\end{array}$ & $\begin{array}{c}-0.002 \\
(-1.377)\end{array}$ & $\begin{array}{c}0.002 \\
(1.618)\end{array}$ \\
\hline \multirow[t]{3}{*}{ UNVOL6 } & Underpriced & $\begin{array}{l}0.005^{* *} \\
(2.166)\end{array}$ & $\begin{array}{l}0.006^{* * *} \\
(3.814)\end{array}$ & $\begin{array}{c}0.001 \\
(0.605)\end{array}$ & $\begin{array}{l}0.003 * * \\
(2.094)\end{array}$ \\
\hline & Overpriced & $\begin{array}{c}0.000 \\
(0.238)\end{array}$ & $\begin{array}{c}0.003 \\
(1.644)\end{array}$ & $\begin{array}{l}0.005^{* *} \\
(2.313)\end{array}$ & $\begin{array}{c}0.002 \\
(0.926)\end{array}$ \\
\hline & Difference & $\begin{array}{c}0.004 * \\
(1.941)\end{array}$ & $\begin{array}{l}0.003 * * \\
(2.131)\end{array}$ & $\begin{array}{l}-0.004 * * * \\
(-2.467)\end{array}$ & $\begin{array}{c}0.002 \\
(1.044)\end{array}$ \\
\hline \multirow[t]{3}{*}{ UNVOL9 } & Underpriced & $\begin{array}{l}0.004 * * \\
(2.034)\end{array}$ & $\begin{array}{l}0.006 * * * \\
(4.105)\end{array}$ & $\begin{array}{c}0.000 \\
(-0.129)\end{array}$ & $\begin{array}{l}0.004^{* *} \\
(2.282)\end{array}$ \\
\hline & Overpriced & $\begin{array}{c}0.001 \\
(0.504)\end{array}$ & $\begin{array}{c}0.003 \\
(1.567)\end{array}$ & $\begin{array}{l}0.006 * * * \\
(2.750)\end{array}$ & $\begin{array}{c}0.002 \\
(1.142)\end{array}$ \\
\hline & Difference & $\begin{array}{c}0.003 \\
(1.550)\end{array}$ & $\begin{array}{l}0.004 * * * \\
(2.455)\end{array}$ & $\begin{array}{l}-0.007 * * * \\
(-3.791)\end{array}$ & $\begin{array}{c}0.002 \\
(0.998)\end{array}$ \\
\hline \multirow[t]{3}{*}{ ABVOL3 } & Underpriced & $\begin{array}{c}0.003 * \\
(1.738)\end{array}$ & $\begin{array}{l}0.004 * * * \\
(3.523)\end{array}$ & $\begin{array}{l}0.003 * * \\
(2.511)\end{array}$ & $\begin{array}{l}0.003 * * \\
(2.185)\end{array}$ \\
\hline & Overpriced & $\begin{array}{c}0.001 \\
(0.531)\end{array}$ & $\begin{array}{c}-0.001 \\
(-0.761)\end{array}$ & $\begin{array}{c}-0.003 \\
(-1.573)\end{array}$ & $\begin{array}{c}0.000 \\
(0.272)\end{array}$ \\
\hline & Difference & $\begin{array}{c}0.002 \\
(1.214)\end{array}$ & $\begin{array}{l}0.005 * * * \\
(4.337)\end{array}$ & $\begin{array}{l}0.007 * * * \\
(4.965)\end{array}$ & $\begin{array}{c}0.002 * \\
(1.843)\end{array}$ \\
\hline \multirow[t]{3}{*}{ DISP $1 * 100$} & Underpriced & $\begin{array}{c}0.083 \\
(1.509)\end{array}$ & $\begin{array}{l}0.076^{* * *} \\
(2.667)\end{array}$ & $\begin{array}{l}0.054 * * \\
(2.071)\end{array}$ & $\begin{array}{c}0.053 * \\
(1.895)\end{array}$ \\
\hline & Overpriced & $\begin{array}{l}0.113^{* * *} \\
(3.875)\end{array}$ & $\begin{array}{c}0.029 \\
(1.143)\end{array}$ & $\begin{array}{c}0.037 \\
(1.321)\end{array}$ & $\begin{array}{c}0.000 \\
(-0.004)\end{array}$ \\
\hline & Difference & $\begin{array}{c}-0.030 \\
(-0.544)\end{array}$ & $\begin{array}{c}0.047 \\
(1.639)\end{array}$ & $\begin{array}{c}0.017 \\
(0.653)\end{array}$ & $\begin{array}{c}0.054 * \\
(1.899)\end{array}$ \\
\hline
\end{tabular}

We re-estimate Equation 1.12 separately for underpriced and overpriced stocks. The proxy of DIVOP is UNVOL3 which corresponds to unexplained trading volume in the three months prior to EPS announcement date. This table shows the coefficients 
and t-statistics (in brackets) of UNVOL3 that are obtained for underpriced and overpriced stocks. We also compute de difference between the coefficient estimated for underpriced and overpriced stocks. Below this difference we show in brackets a t-statistic of a test in which the null hypothesis is that the difference is zero. *,** and *** represent statistical significance with a confidence level of $90 \%, 95 \%$ and $99 \%$, respectively. The independent variables are MISP1-5. MISP1 is the logarithm of the ratio between market value of equity and a theoretical value (Frankel and Lee, 1998). MISP2 is the difference between the logarithm of the market value of equity and the logarithm of expected market value of equity (Rhodes-Kropf et al., 2005). MISP3 refers to the logarithm of the ratio between firms' capital to sales ratio and the median capital to sales ratio of their corresponding industry (Berger and Ofek, 1995). MISP4 corresponds to the logarithm of the ratio of firms' market-to-book ratio and median market-tobook ratio of their corresponding industry (Walking and Edmisted, 1985; Rau and Vermaelen, 1998).

\section{Discussion and concluding remarks}

The association between DIVOP and stock mispricing can be justified through two theories. The first one indicates that in the presence of DIVOP, prices have the tendency to incorporate the opinion of the most optimistic investors. Optimistic investors can always buy a stock but pessimistic investors can only sell a stock if they already own it, otherwise they have to resort to short-selling, which has costs. This idea was primarily proposed by Miller (1977). The second theory is based on the model developed by Merton (1987). In sum, investors may not be able to hold diversified portfolios due to information risk. Note that DIVOP tends to be generated in poor information environments (Berkman et al. 2009; Rajgopal and Venkatachalam, 2011). Due to increased risk, in Merton's setting, investors will demand higher returns. As a result, stocks subjected to larger DIVOP, will tend to be underpriced.

Consistent with both Miller (1977) and Merton (1987), and in line with available empirical evidence (Berkman et al., 2009; Carlin et al., 2014; Al-Nasseri and Ali, 2018), we show that DIVOP is associated with stock mispricing. Still, prior empirical evidence tends to be short-term driven. We show that the association between DIVOP and stock mispricing holds in a yearly perspective. More importantly, other studies that provided empirical evidence of this association do not actually measure mispricing. Ours is the first study to apply explicit measures of mispricing, instead of interpreting abnormal future stock returns as a signal of contemporaneous mispricing, as all prior empirical research does. To test the association between DIVOP and stock mispricing, we resort to very different and independent measures of DIVOP (IVOL, unexpected trading volume and DISP) and a total of five measures of mispricing (Aabo et al., 2017). We also applied many different robustness tests.

Albeit both the work of Miller (1977) and Merton (1987) suggest that DIVOP leads to stock mispricing, Miller's theory is consistent with mispricing being a reflection of overpricing, while Merton's setting points that mispricing actually represents underpricing. Available literature is mixed. Prior empirical literature tends to be more in line with Miller's (Diether et al., 2002; David, 2008; Berkman et al., 2009), while neoclassical model-based literature (Varian, 1985; Andersen et al., 2005) tends to support Merton's setting. The tests that we compute are based on a yearly perspective and point out that the relationship between DIVOP and stock mispricing is stronger for underpriced stocks. Theoretically, this suggests that DIVOP reflects information risk (Merton, 1987). This is in line with Jiang et al. (2009), Rajgopal and Venkatachalam (2011) and Berrada and Hugonnier (2013), who associate information risk with idiosyncratic risk. Furthermore, these results are also in accordance with Andresen et al. (2005), who argue that DIVOP is a price risk factor.

It must be highlighted that our conclusions do not imply that DIVOP cannot lead to overpricing in the short-term or in specific contexts. Indeed, the results in this study, are consistent with recent research that hints that the evidence of the overpricing hypothesis tend to be very context specific. For instance, Al-Nasseri and Ali (2018) show that the overpricing hypothesis only holds in bull markets. Veenman and Verwijmeren (2020) argues that the predictive power of DISP is concentrated only around earnings announcement dates. Also, tests based on earnings announcements can be tricky, since many factors affect the outcome of these announcements, even the weekday in which it takes place (DellaVigna and Pollet, 2009; Louis and Sun, 2010). Finally, our conclusions are consistent with the recent study by Cao et al. (2020) who find that low investor attention tends to ease both DIVOP and lower stock returns.

Our study has two main implications. Small investors with medium-term horizons should be aware of stocks that face high DIVOP. This analysis shows that, independently if an investor is right or wrong, DIVOP works as a price risk factor and consequently stocks with larger DIVOP will tend to be underpriced. Secondly, our results are consistent with DIVOP reflecting an information risk factor (Rajgopal and Venkatachalam, 2011; Berrada and Hugonnier, 2013), thus, firms have incentives to provide high-quality and explicit information to limit DIVOP and avoid being underpriced.

Future research, may address the association between DIVOP and stock mispricing in other stock markets in order for researchers to understand the pervasiveness of this phenomena. Also, future studies may assess the relationship 
between DIVOP and stock mispricing, using a short-term perspective, but using explicit measures of mispricing, instead of relying on future stock returns. Future studies that are able to link the available short-term evidence and our analysis, which relies on a yearly perspective, would be very useful.

\section{References}

Aabo, T., Pantzalis, C., \& Park, J. C. (2017). Idiosyncratic volatility: An indicator of noise trading? Journal of Banking \& Finance, 75, 136-151.

Al-Nasseri, A., \& Ali, F. M. (2018). What does investors' online divergence of opinion tell us about stock returns and trading volume?. Journal of Business Research, 86, 166-178.

Anderson, E. W., Ghysels, E., \& Juergens, J. L. (2005). Do heterogeneous beliefs matter for asset pricing?. The Review of Financial Studies, 18(3), 875-924.

Ang, A., Hodrick, R. J., Xing, Y., \& Zhang, X. (2006). The cross-section of volatility and expected returns. The Journal of Finance, 61(1), 259-299.

Ang, A., Hodrick, R. J., Xing, Y., \& Zhang, X. (2009). High idiosyncratic volatility and low returns: International and further US evidence. Journal of Financial Economics, 91(1), 1-23.

Angelidis, T., \& Tessaromatis, N. (2008). Idiosyncratic volatility and equity returns: UK evidence. International Review of Financial Analysis, 17(3), 539-556.

Aslanidis, N., Christiansen, C., Lambertides, N., \& Savva, C. S. (2019). Idiosyncratic volatility puzzle: influence of macrofinance factors. Review of Quantitative Finance and Accounting, 52(2), 381-401.

Atmaz, A., \& Basak, S. (2018). Belief dispersion in the stock market. The Journal of Finance, 73(3), 1225-1279.

Barron, O. E., Kim, O., Lim, S. C., \& Stevens, D. E. (1998). Using analysts' forecasts to measure properties of analysts' information environment. Accounting Review, 421-433.

Basak, S. (2005). Asset pricing with heterogeneous beliefs. Journal of Banking \& Finance, 29(11), 2849-2881.

Beaver, W. H. (1968). The information content of annual earnings announcements. Journal of accounting research, 67-92.

Berger, P. G., \& Ofek, E. (1995). Diversification's effect on firm value. Journal of financial economics, 37(1), 39-65.

Berkman, H., Dimitrov, V., Jain, P. C., Koch, P. D., \& Tice, S. (2009). Sell on the news: Differences of opinion, short-sales constraints, and returns around earnings announcements. Journal of Financial Economics, 92(3), 376-399.

Berrada, T., \& Hugonnier, J. (2013). Incomplete information, idiosyncratic volatility and stock returns. Journal of Banking \& Finance, 37(2), 448-462.

Boehme, R. D., Danielsen, B. R., Kumar, P., \& Sorescu, S. M. (2009). Idiosyncratic risk and the cross-section of stock returns: Merton (1987) meets Miller (1977). Journal of Financial Markets, 12(3), 438-468.

Brandt, M. W., Brav, A., Graham, J. R., \& Kumar, A. (2009). The idiosyncratic volatility puzzle: Time trend or speculative episodes?. The Review of Financial Studies, 23(2), 863-899.

Bulmer, M. G. 1979. Principles of Statistics. Dover.

Campbell, J. Y., Lettau, M., Malkiel, B. G., \& Xu, Y. (2001). Have individual stocks become more volatile? An empirical exploration of idiosyncratic risk. The Journal of Finance, 56(1), 1-43.

Cao, Z., Kilic, O., \& Wang, X. (2020). Investor Attention, Divergence of Opinions, and Stock Returns. Journal of Behavioral Finance, 1-15.

Carhart, M. M. (1997). On persistence in mutual fund performance. The Journal of finance, 52(1), 57-82.

Carlin, B. I., Longstaff, F. A., \& Matoba, K. (2014). Disagreement and asset prices. Journal of Financial Economics, 114(2), 226-238.

Cerqueira, A., \& Pereira, C. (2018). Does idiosyncratic return volatility capture information or noise?. International Journal of Trade and Global Markets, 11(4), 270-292.

Chang, X., Tam, L. H., Tan, T. J., \& Wong, G. (2007). The real impact of stock market mispricing-Evidence from Australia. Pacific-Basin Finance Journal, 15(4), 388-408.

Chatterjee, S., John, K., \& Yan, A. (2012). Takeovers and divergence of investor opinion. The Review of Financial Studies, 25(1), 227-277.

Chen, J., Hong, H., \& Stein, J. C. (2002). Breadth of ownership and stock returns. Journal of financial Economics, 66(2-3), 171205.

Chen, S., \& Jiambalvo, J. (2004). The relation between dispersion in analysts' forecasts and stock returns: Optimism versus drift. Unpublished working paper, University of Washington.

Danthine, J. P., \& Moresi, S. (1993). Volatility, information and noise trading. European Economic Review, 37(5), 961-982.

David, A. (2008). Heterogeneous beliefs, speculation, and the equity premium. The Journal of Finance, 63(1), 41-83.

De Bondt, W. F., \& Thaler, R. (1985). Does the stock market overreact?. The Journal of finance, 40(3), 793-805.

DellaVigna, S., \& Pollet, J. M. (2009). Investor inattention and Friday earnings announcements. The Journal of Finance, 64(2), 709-749.

Dennis, P., \& Strickland, D. (2004). The determinants of idiosyncratic volatility. Unpublished working paper, University of Virginia. 
Diether, K. B., Malloy, C. J., \& Scherbina, A. (2002). Differences of opinion and the cross section of stock returns. The Journal of Finance, 57(5), 2113-2141.

Dong, M., Hirshleifer, D., Richardson, S., \& Teoh, S. H. (2006). Does investor misvaluation drive the takeover market?. The Journal of Finance, 61(2), 725-762.

Doukas, J. A., Chansog (Francis) Kim, \& Pantzalis, C. (2010). Arbitrage risk and stock mispricing. Journal of Financial and Quantitative Analysis, 907-934.

Doukas, J. A., Kim, C., \& Pantzalis, C. (2006a). Divergence of opinion and equity returns. Journal of Financial and Quantitative Analysis, 573-606.

Doukas, J. A., Kim, C., \& Pantzalis, C. (2006b). Divergence of opinion and equity returns under different states of earnings expectations. Journal of Financial Markets, 9(3), 310-331.

Fama, E. F. (1965). The behavior of stock-market prices. The journal of Business, 38(1), 34-105.

Fama, E. F. (1970). Efficient capital markets: A review of theory and empirical work. The journal of Finance, 25(2), $383-417$.

Fama, E. F. (1973). A note on the market model and the two-parameter model. The Journal of Finance, 28(5), 1181-1185.

Fama, E. F., \& French, K. R. (1993). Common risk factors in the returns on stocks and bonds. Journal of financial economics, 33(1), 3-56.

Fama, E. F., \& French, K. R. (1997). Industry costs of equity. Journal of Financial Economics, 43(2), 153-193.

Fama, E. F., \& French, K. R. (2015). A five-factor asset pricing model. Journal of financial economics, 116(1), 1-22.

Fink, J., Fink, K. E., Grullon, G., \& Weston, J. P. (2010). What drove the increase in idiosyncratic volatility during the internet boom?. Journal of Financial and Quantitative Analysis, 45(5), 1253-1278.

Frankel, R., \& Lee, C. M. (1998). Accounting valuation, market expectation, and cross-sectional stock returns. Journal of Accounting and economics, 25(3), 283-319.

Gao, S., Brockman, P., Meng, Q., \& Yan, X. (2020). Differences of opinion, institutional bids, and IPO underpricing. Journal of Corporate Finance, 60, 101540.

Garfinkel, J. A. (2009). Measuring investors' opinion divergence. Journal of Accounting Research, 47(5), $1317-1348$.

Garfinkel, J. A., \& Sokobin, J. (2006). Volume, opinion divergence, and returns: A study of post-earnings announcement drift. Journal of Accounting Research, 44(1), 85-112.

Gaspar, J. M., \& Massa, M. (2006). Idiosyncratic volatility and product market competition. The Journal of Business, 79(6), 3125-3152.

Gu, M., Kang, W., \& Xu, B. (2018). Limits of arbitrage and idiosyncratic volatility: Evidence from China stock market. Journal of Banking \& Finance, 86, 240-258.

Guo, H., \& Savickas, R. (2008). Average idiosyncratic volatility in G7 countries. The review of financial studies, 21(3), 12591296.

Han, Y., \& Lesmond, D. (2011). Liquidity biases and the pricing of cross-sectional idiosyncratic volatility. The Review of Financial Studies, 24(5), 1590-1629.

Heston, S. L., \& Sadka, R. (2008). Seasonality in the cross-section of stock returns. Journal of Financial Economics, 87(2), 418445.

Hu, Y., Zhao, T., \& Zhang, L. (2020). Noise trading, institutional trading, and opinion divergence: Evidence on intraday data in the Chinese stock market. International Review of Economics \& Finance.

Jacobs, H., \& Müller, S. (2020). Anomalies across the globe: Once public, no longer existent?. Journal of Financial Economics, 135(1), 213-230.

Jarrow, R. A., \& O'Hara, M. (1989). Primes and scores: An essay on market imperfections. The Journal of Finance, 44(5), 12631287.

Jiang, G. J., Xu, D., \& Yao, T. (2009). The information content of idiosyncratic volatility. Journal of Financial and Quantitative Analysis, 44(1), 1-28.

Johnson, T. C. (2004). Forecast dispersion and the cross section of expected returns. The Journal of Finance, 59(5), 1957-1978.

Karpoff, J. M. (1987). The relation between price changes and trading volume: A survey. Journal of Financial and quantitative Analysis, 109-126.

Keloharju, M., Linnainmaa, J. T., \& Nyberg, P. (2020). Are return seasonalities due to risk or mispricing?. Journal of Financial Economics.

Kim, O., \& Verrecchia, R. E. (1991a). Trading volume and price reactions to public announcements. Journal of accounting research, 29(2), 302-321.

Kim, O., \& Verrecchia, R. E. (1991b), "Market Reactions to Anticipated Announcements," Journal of Financial Economics, 30, 273-309.

Li, H. (2020). Volatility spillovers across European stock markets under the uncertainty of Brexit. Economic Modelling, 84, 112.

Louis, H., \& Sun, A. (2010). Investor inattention and the market reaction to merger announcements. Management Science, 56(10), 1781-1793.

Malagon, J., Moreno, D., \& Rodríguez, R. (2015). The idiosyncratic volatility anomaly: Corporate investment or investor mispricing?. Journal of Banking \& Finance, 60, 224-238. 
Merton, R. (1987). A Simple Model of Capital Market Equilibrium with Incomplete Information. Journal of Finance, 42(3), 483510.

Miller, E. M. (1977). Risk, uncertainty, and divergence of opinion. The Journal of finance, 32(4), 1151-1168.

Nichols, D. R. (1989). The handbook of investor relations. Irwin Professional Pub.

Park, C. (2005). Stock return predictability and the dispersion in earnings forecasts. The Journal of Business, 78(6), $2351-2376$.

Pontiff, J. (1996). Costly arbitrage: Evidence from closed-end funds. The Quarterly Journal of Economics, 111(4), $1135-1151$.

Qian, X. (2014). Small investor sentiment, differences of opinion and stock overvaluation. Journal of Financial Markets, 19, 219-246.

Qu, S., Starks, L., \& Yan, H. (2003). Risk, dispersion of analyst forecasts and stock returns. University of Texas at Austin Working Paper, 1-33.

Rajgopal, S., \& Venkatachalam, M. (2011). Financial reporting quality and idiosyncratic return volatility. Journal of Accounting and Economics, 51(1-2), 1-20.

Ramiah, V., Pham, H. N., \& Moosa, I. (2017). The sectoral effects of Brexit on the British economy: early evidence from the reaction of the stock market. Applied Economics, 49(26), 2508-2514.

Rau, P. R., \& Vermaelen, T. (1998). Glamour, value and the post-acquisition performance of acquiring firms. Journal of financial economics, 49(2), 223-253.

Rhodes-Kropf, M., Robinson, D. T., \& Viswanathan, S. (2005). Valuation waves and merger activity: The empirical evidence. Journal of Financial Economics, 77(3), 561-603.

Schipper, K. (1991). Analysts' forecasts. Accounting horizons, 5(4), 105.

Sharpe, W. F. (1963). A simplified model for portfolio analysis. Management science, 9(2), 277-293.

Stambaugh, R. F., Yu, J., \& Yuan, Y. (2015). Arbitrage asymmetry and the idiosyncratic volatility puzzle. The Journal of Finance, 70(5), 1903-1948.

Trimech, A., \& Kortas, H. (2009). Multiscale carhart four-factor pricing model: Application to the french market. IUP Journal of Financial Risk Management, 6(2), 61.

Varian, H. R., 1985, "Divergence of Opinion in Complete Markets," Journal of Finance, 40, 309- 317.

Veenman, D., \& Verwijmeren, P. (2020). Earnings Surprises, Mispricing, and the Dispersion Anomaly. Mispricing, and the Dispersion Anomaly (February 6, 2020).

Walkling, R. A., \& Edmister, R. O. (1985). Determinants of tender offer premiums. Financial Analysts Journal, 41(1), $27-37$.

Warr, R. S., Elliott, W. B., Koëter-Kant, J., \& Öztekin, Ö. (2012). Equity mispricing and leverage adjustment costs. Journal of Financial and Quantitative Analysis, 589-616.

Xiong, X., Meng, Y., Joseph, N. L., \& Shen, D. (2020). Stock mispricing, hard-to-value stocks and the influence of internet stock message boards. International Review of Financial Analysis, 72, 101576.

Xu, Y., \& Malkiel, B. G. (2003). Investigating the behavior of idiosyncratic volatility. The Journal of Business, $76(4), 613-645$.

Yu, J. (2011). Disagreement and return predictability of stock portfolios. Journal of Financial Economics, 99(1), $162-183$.

Zhang, L., Farooq, Q., Zhang, Y., Liu, X., \& Hao, Y. (2020). Fair value and mispricing: how domestic earnings transparency of listed firms leads to global financial stability. European Journal of International Management, 14(1), 173-193. 